\title{
Fuerzas de repulsión de aditivos superplastificantes en sistemas de escoria granulada de horno alto en medios alcalinos, desde medidas de AFM a propiedades reológicas
}

\section{Repulsion forces of superplasticizers on ground granulated blast furnace slag in alkaline media, from AFM measurements to rheological properties}

\author{
$\underline{\text { M. Palacios }}^{(*, * *)}$, P. Bowen ${ }^{(* * *)}$, M. Kappl(****), H-J. Butt(****), M. Stuer(***), C. Pecharromán ${ }^{(* * * * *),}$ \\ U. Aschauer ${ }^{(* * * * * *)}$, F. Puertas ${ }^{(*)}$
}

Recepción/Received: 14-IV-12

Aceptación/Accepted: 4-V-12

RESUMEN

En este trabajo se ha estudiado la repulsión electrostática y estérica inducida por diferentes aditivos superplastificantes en sistemas de escoria de horno alto en medios alcalinos. Se han estudiado aditivos superplastificantes basados en naftaleno, melamina, copolímeros vinílicos y basados en policarboxilato. Estos aditivos inducen en la escoria un potencial zeta negativo, entre -3 y $-10 \mathrm{mV}$. Por primera vez, se ha determinado el grosor de la capa de aditivo adsorbido sobre la escoria mediante microscopía de fuerzas atómicas (AFM). Para modelizar las fuerzas de interacción entre partículas, se ha determinado la constante efectiva de Hamaker de la escoria a partir de las propiedades dieléctricas de una muestra de escoria obtenida mediante sinterización spark plasma sintering. Los resultados obtenidos concluyen que el mecanismo de dispersión de los superplastificantes estudiados en este trabajo está gobernado fundamentalmente por la repulsión estérica. Utilizando el modelo YODEL se ha podido predecir el esfuerzo de cizalla umbral de sistemas de escoria con y sin superplastificantes. Los resultados calculados están de acuerdo con los valores de esfuerzo de cizalla determinados experimentalmente.

Palabras clave: dispersión, escoria granulada de horno alto, superficies, suspensiones, reología.

\section{SUMMARY}

The electrostatic and steric repulsion induced by different superplasticizers on ground granulated blast furnace slag in alkaline media have been studied. The superplasticizers were sulfonated naphthalene, sulfonated melamine, vinyl copolymer, and polycarboxylate- based admixtures. With these superplasticizers the slag suspensions had negative zeta potentials, ranging from -3 to $-10 \mathrm{mV}$. For the first time the adsorbed layer thicknesses for superplasticizers on slag using colloidal probe atomic force microscopy has been measured. To model the interparticle force interactions an effective Hamaker constant was computed from dielectric properties measured on a dense slag sample produced by spark plasma sintering. The obtained results conclude that the dispersion mechanism for all the superplasticizers studied in the present work is mainly dominated by the steric repulsion. Results were then used in a yield stress model, YODEL, to predict the yield stress with and without the superplasticizers. Predictions of the yield stress agreed well with experimental results.

Keywords: dispersion, ground granulated blast furnace slag, surfaces, suspensions, rheology.

\footnotetext{
(*) Instituto de Ciencias de la Construcción Eduardo Torroja (IETcc-CSIC) (Madrid, España).

(**) Institute for Building Materials. ETHZ (Zurich, Switzerland).

$(* * *)$ École Polytechnique Fédérale de Lausanne (EPFL) (Lausanne, Switzerland).

$(* * * *)$ Max Planck Institute for Polymer Research (Mainz, Germany).

$(* * * * *)$ Instituto de Ciencias de Materiales de Madrid (ICMM-CSIC) (Madrid, España).

$(* * * * * *)$ Materials theory, ETHZ (Zürich, Switzerland).
} 


\section{INTRODUCCIÓN}

En los últimos años los aditivos superplastificantes se han convertido en un componente fundamental del hormigón. Estos aditivos mejoran sus propiedades reológicas y disminuyen la demanda de agua incrementando las propiedades mecánicas y durabilidad. Los mecanismos involucrados y la compatilibilidad aditivo-cemento Portland (OPC) han sido estudiados y descritos en numerosos artículos (1-5). Estos trabajos concluyen que los aditivos superplastificantes se adsorben sobre la superficie de las partículas de cemento induciendo su dispersión mediante fuerzas de repulsión de tipo electrostático y/o estérico. De este modo, se libera el agua atrapada en el interior de los flóculos incrementando la fluidez del sistema y modificando la fracción efectiva de volumen de sólidos $(1,3)$. Estudios previos han confirmado que en el caso de los aditivos derivados de naftaleno y melamina, el principal mecanismo de dispersión es la repulsión electrostática, mientras que para los aditivos basados en policarboxilato, la repulsión electrostática es pequeña y la dispersión inducida es debida a fuerzas de tipo estérico (6-9).

El efecto de los aditivos superplastificantes en cementos de escoria activada alcalinamente (AAS) no se ha estudiado en profundidad. Estos cementos se obtienen al mezclar una disolución fuertemente alcalina con escoria granulada de horno alto. Su proceso de fabricación presenta ventajas de tipo energético y medioambiental con respecto a la fabricación de $\operatorname{OPC}(10,11)$.

Estudios previos sugieren el diferente comportamiento de aditivos superplastificantes en sistemas de OPC con respecto a sistemas de AAS (12-15). La cantidad de aditivo adsorbido en pastas de AAS es significativamente menor que en pastas de OPC. La razón de este diferente comportamiento podría ser que en OPC una elevada cantidad de aditivo es adsorbida por los aluminatos anhidros $\left(\mathrm{C}_{3} \mathrm{~A}\right)$ e hidratados (etringita) y a la posible intercalación del aditivo formando una fase organomineral; mientras que los cementos de AAS carecen de ambos compuestos, ya que la escoria carece de $C_{3} A$ (12). Además, la adsorción de los aditivos superplastificantes es independiente del $\mathrm{pH}$ de la disolución alcalina utilizada como activador de la escoria.

Sin embargo, el efecto fludificante inducido por los aditivos superplastificantes en cementos de AAS es muy diferente al inducido en pastas de OPC y depende tanto del tipo de aditivo utilizado como de la naturaleza y $\mathrm{pH}$ de la disolución activadora. Cuando se utiliza $\mathrm{NaOH}(\mathrm{pH}=11,7)$ como disolución activadora, bajas dosis (menores de 0,45 $\mathrm{mg}$ superplastificante/g escoria) de aditivos basados en naftaleno, melanina y copolímeros vinílicos disminuyen el esfuerzo de cizalla umbral hasta un $90 \%$ en pastas de AAS. Esta disminución es significativamente superior a la

\section{INTRODUCTION}

In recent years, superplasticizer admixtures have become an essential component of concrete. Such admixtures improve the rheological properties of concrete and decrease the water demand increasing its mechanical strength and durability. The mechanisms involved and superplasticizer compatibility with ordinary Portland cement (OPC) have been studied and described in numerous articles (1-5). These papers report that such admixtures are adsorbed onto the surface of cement particles, causing inter-particle electrostatic and/or steric repulsion. By dispersing agglomerated particles or flocs, the water retained in the flocs is released, enhancing flowability by modifying the effective solids volume fraction $(1,3)$. Previous studies have suggested that for naphtalene-based or melamine-based admixtures the main dispersion mechanism is electrostatic repulsion, while for polycarboxylate-based admixtures, the electrostatic repulsion is accepted to be small and the main dispersion mechanism is steric repulsion (6-9).

The effect of superplasticizers on alkali-activated slag (AAS) cements has, however, not been deeply studied. These AAS cements are obtained by mixing high alkaline solutions with ground granulated blast furnace slag. Its manufacturing process has energy-saving and environmental advantages with respect to OPC manufacture $(10,11)$.

Previous studies have confirmed the different behaviour of superplasticizers in OPC systems with respect to alkaline-activated slag systems (12-15). The amount of superplasticizer admixture adsorbed on the slag particles in AAS pastes is significantly lower than on OPC pastes. The reason for this different behaviour could be due to the fact that in OPC a high amount of admixture is adsorbed by ettringite and possible intercalation in an organo mineral phase whereas in AAS cements these two hydration products are not formed because slags do not contain $C_{3} A$ (12). Additionally, the adsorption of the superplasticizer admixtures in AAS cements is independent of the $\mathrm{pH}$ of the alkaline solution used as an activator for the slag.

However, the fluidizing effect of superplasticizers in AAS cements differs from the OPC pastes and depends on both the type of admixture and, especially, the nature and $\mathrm{pH}$ of the alkaline activator solution. When $\mathrm{NaOH}$ $(\mathrm{pH}=11.7)$ solution is used as the activator, low dosages (lower than $0.45 \mathrm{mg}$ superplasticizer/g slag) of naphthalene-, melamine- and vinyl copolymer-based superplasticizers all induce a decrease of the yield stress by up to $90 \%$ in the AAS pastes. This decrease is significantly higher than in OPC pastes. However, most 
que los mismos aditivos inducen en pastas de OPC. La mayoría de los aditivos superplastificantes, a pesar de adsorberse sobre la escoria en los sistemas de AAS, disminuyen sus propiedades fluidificantes cuando el activador utilizado es $\mathrm{NaOH}$ con $\mathrm{pH}=13,6$. Ello es debido a que esos aditivos no son químicamente estables en un medio tan fuertemente alcalino $(15,16)$. A este respecto, estudios previos $(15,16)$ han demostrado que los aditivos copolímeros vinílicos y los basados en policarboxilatos sufren hidrólisis alcalina a $\mathrm{pH}=13,6$; solo el aditivo derivado de naftaleno conserva sus propiedades dispersantes debido a su estabilidad química (16). La adición de pequeñas dosis de naftaleno (1,26 mg naftaleno/g escoria) a pastas de AAS con una disolución de $\mathrm{NaOH}(\mathrm{pH}=13.6)$ disminuyen el esfuerzo de cizalla umbral hasta en un $98 \%$ (12).

El comportamiento reológico de las pastas de AAS está determinado por las fuerzas entre las partículas en suspensión y el contenido de sólidos (relación agua/cemento). Las fuerzas entre partículas son atractivas de van der Waals y repulsivas de tipo electrostático y estérico. Dichas fuerzas dependen del tamaño y naturaleza de la partícula (las propiedades dieléctricas y ópticas determinan las fuerzas atractivas a través de la constante de Hamaker), de la fase líquida y su concentración iónica, del potencial superficial de la partícula y del grosor de la capa de aditivo adsorbido. Sin embargo, los mecanismos de dispersión de aditivos superplastificantes en cementos de AAS no han sido estudiados en profundidad hasta el momento y las diferencias con respecto a OPC no han sido establecidas.

El objetivo del presente trabajo ha sido estudiar y entender la relativa importancia de las fuerzas de repulsión electrostática y estérica inducida por diferentes aditivos superplastificantes (basados en naftaleno, melamina, copolímero vinílico y basados en policarboxilato) en sistemas de escoria granulada de horno alto en medios alcalinos. Con esta información, ha sido posible utilizar el modelo reológico YODEL (17) para precedir los cambios en las propiedades reológicas de las correspondientes pastas y, en particular, en el esfuerzo de cizalla umbral, un parámetro determinante en la tecnología del cemento.

Para conocer las fuerzas de dispersión estérica, se ha determinado el grosor de la capa de aditivo adsorbido sobre sustratos sinterizados de alumina (sistema modelo) y de escoria mediante Microscopía de Fuerzas Atómicas (AFM). Para elucidar el mecanismo de estabilización, se han modelizado las fuerzas entre partículas utilizando el programa Hamaker (18). Debido a la falta de adecuados datos experimentales de las propiedades dieléctricas de las fases de cemento, se han realizado métodos de escalamiento (scaling methods) que proporcionan una estimación de la constante de Hamaker of the superplasticizers, despite the fact that they adsorb on the slag, lose their fluidizing properties in $\mathrm{pH} 13.6$ $\mathrm{NaOH}$-activated slag pastes as they are not chemically stable in such strongly alkaline media $(15,16)$. In this respect, previous studies $(15,16)$ have shown that vinyl copolymer and polycarboxylate based admixtures experience alkaline hydrolysis at $\mathrm{pH}=13.6$. Only the naphthalene-based admixture keeps its dispersing properties as a consequence of its chemical stability (16). In this case, dosages as low as $1.26 \mathrm{mg}$ naphthalene/g slag are observed to induce the maximum reduction in yield stress (98\%) for the $\mathrm{pH} 13.6 \mathrm{NaOH}$ activated slag pastes (12).

The rheological behaviour of AAS pastes is determined by the interparticle forces in suspension as well as the solid content (water to binder ratio). Interparticle forces are attractive van der Waals and repulsive electrostatic and steric forces. They depend on the particle size, the particle nature (the dielectric and optical properties determine the attractive forces via the Hamaker constant), the intervening liquid phase and its ionic concentration, the particle surface potential and the adsorbed layer thickness of any polymeric admixtures. The dispersion mechanisms of superplasticizers in AAS cements have not been studied in detail and the differences with respect to OPC have not yet been clearly established.

The aim of the present work is to study and understand the relative importance of the electrostatic and steric repulsion induced by different superplasticizers (sulfonated naphthalene, sulfonated melamine, vinyl copolymer and polycarboxylate-based admixtures) in ground granulated blast furnace slag in alkaline media. With this information it was possible to use a rheological model, YODEL (17) to predict the changes in the rheological properties of the corresponding pastes and in particular the yield stress, a key parameter in cement technology.

To determine the steric repulsion, the adsorbed layer thickness of admixture has been established by colloidal probe Atomic Force Microscopy (AFM) on both model alumina and sintered blast furnace slag substrates. To help elucidate the stabilization mechanism interparticle force modelling has been carried out using the Hamaker software (18). Interparticle force modelling in cementitious materials has had to resort to scaling methods to provide estimations of Hamaker constants because of the lack of adequate experimental data on the dielectric properties of cement phases (19). Because 
(19). Además, la naturaleza amorfa de la escoria de horno alto es la responsable de que la correlación con las constantes de Hamaker recogidas en la bibliografía no sea aceptable. Por ello se han determinado las propiedades dieléctricas de una escoria de horno alto sinterizada y se ha realizado una estimación de la constante de Hamaker efectiva, lo que ha permitido obtener una mejor evaluación de las fuerzas entre partículas en las suspensiones de escoria. De este modo ha sido posible determinar el mecanismo de dispersión para las pastas de AAS en presencia de aditivos superplastificantes y predecir el esfuerzo de cizalla umbral a través del modelo reológico YODEL.

Tanto la carga superficial efectiva de las partículas (potencial zeta) como el grosor de la capa de aditivo adsorbida son parámetros clave para establecer el mecanismo de dispersión de aditivos superplastificantes. Para ello, se ha determinado el efecto de 4 aditivos superplastificantes con diferentes estructuras en el potencial zeta de suspensiones de escoria en medios alcalinos mediante métodos electroacústicos. El grosor de la capa de aditivo adsorbida se ha determinado a través de Microscopía de Fuerzas Atómicas (AFM).

\section{MATERIALES Y MÉTODOS}

Se han utilizado 4 aditivos superplastificantes comerciales con diferente composición química: derivado de melamina (M), derivado de naftaleno (NF), copolímero vinílico (V) y basado en policarboxylato (PC). Las características físicas y químicas de estos aditivos se muestran en las Tablas 1 y 2 y una descripción más detallada de los polímeros se recoge en otros trabajos $(16,20)$. of the amorphous nature of the blast furnace slag, correlation with the previously used Hamaker constants was not obvious. To overcome this difficulty an evaluation of the dielectric properties of sintered blast furnace slag and an estimation of an effective Hamaker constant has been made to allow the best possible evaluation of the interparticle forces for blast furnace slag suspensions. This has allowed us to evaluate the dispersion mechanism for these slag pastes in alkaline media and superplasticizer combinations and predict the yield stress using the rheological model YODEL.

The two key parameters to establish the mechanism of superplasticizers dispersion are the effective surface charge (zeta potential) and adsorbed layer thickness $\left(L_{\text {ads }}\right)$. The effect of 4 different superplasticizers on the zeta potential of slag suspensions in alkaline media was measured using electroacoustic methods. The adsorbed thickness layer of these admixtures has been investigated by colloidal probe Atomic Force Microscopy (AFM).

\section{MATERIALS AND METHODS}

The four different commercial superplasticizer admixtures used were sulfonated melamine (M), sulfonated naphthalene (NF), vinyl copolymer (V), and a polycarboxylate-based (PC) admixtures. Physical and chemical characteristics of the superplasticizers are given in Tables 1 and 2 and a more detailed characterization of the polymers is described in a different work $(16,20)$.

Tabla 1 / Table 1

Caracterización físico-química de los superplastificantes. Physical and chemical characteristics of superplasticizers.

\begin{tabular}{|c|c|c|c|c|}
\hline Aditivo / Admixture & $\begin{array}{c}\text { Basado en naftaleno / } \\
\text { Naphthalene-based (NF) }\end{array}$ & $\begin{array}{c}\text { Basado en melamina / } \\
\text { Melamine-based (M) }\end{array}$ & $\begin{array}{c}\text { Copolímero vinílico / Vinyl } \\
\text { copolymer (V) }\end{array}$ & $\begin{array}{c}\text { Basado en policarboxilato / } \\
\text { Polycarboxylate-based (PC) }\end{array}$ \\
\hline $\begin{array}{c}\text { Contenido en sólidos / Solids } \\
\text { content (\%) }\end{array}$ & 40 & 40 & 25 & 35 \\
\hline $\mathrm{pH}$ & 7.86 & 8.22 & 6.80 & 4.65 \\
\hline Densidad / Density (g/cm) & 1.20 & 1.23 & 1.14 & 21.09 \\
\hline $\begin{array}{c}\text { Viscosidad intrísica / Intrinsic } \\
\text { viscosity (ml/g) }\end{array}$ & 6.09 & 8.63 & 52.87 & 70.37 \\
\hline $\begin{array}{c}\text { Viscosidad rotacional / } \\
\text { Rotational viscosityl (mPa s) }\end{array}$ & 58.67 & 57.27 & 24.13 & 51.97 \\
\hline$\%$ C & 46.59 & 29.03 & 34.05 & - \\
\hline \% N & 0.69 & 22.39 & 3.11 & - \\
\hline$\%$ S & 1.47 & 8.34 & 6.83 & 6800 \\
\hline Na (ppm) & 42400 & 39350 & 38950 & 16 \\
\hline K (ppm) & 320 & 2930 & - & $3: 1$ \\
\hline $\begin{array}{c}\text { Ester/Carboxilato / } \\
\text { Ester:Carboxylate }\end{array}$ & - & - & & \\
\hline
\end{tabular}


Tabla 2 / Table 2

Pesos moleculares $\left(M_{w}\right.$ and $\left.M_{n}\right)$, indice de polidispersidad (PDI) de los aditivos.

Molar masses $\left(M_{w}\right.$ and $\left.M_{n}\right)$, polydispersity index (PDI) for the admixtures.

\begin{tabular}{|c|c|c|c|}
\hline Aditivo / Admixture & $\mathrm{M}_{\mathrm{w}}(\mathrm{Da})$ & $M_{n}(D a)$ & PDI $\left(M_{w} / M_{n}\right)$ \\
\hline $\mathrm{NF}$ & 5384 & 3338 & 1.6 \\
\hline M & 15804 & 8498 & 1.9 \\
\hline $\mathrm{V}$ & 28800 & 13814 & 2.1 \\
\hline PC & 24275 & 11962 & 2.0 \\
\hline
\end{tabular}

\subsection{Efecto de los aditivos superplastificantes en el potencial zeta de suspensiones de escoria}

\subsubsection{Materiales utilizados}

La composición química de la escoria granulada de horno alto española utilizada se muestra en la Tabla 3. La Figura 1 muestra la distribución de tamaño de partícula de la escoria determinada mediante difracción láser (MALVERN MASTERSIZER S). Para ello la escoria se dispersó previamente en isopropanol. La escoria tiene un contenido en fase vítrea del $99 \%$ y una superficie específica de $325 \mathrm{~m}^{2} / \mathrm{kg}$.

\subsection{Effect of the superplasticizers on the zeta potential of slag suspensions}

\subsubsection{Materials used}

The chemical composition of the Spanish ground granulated blast furnace slag used is given in Table 3. Fig. 1 shows the particle size distribution of the slag measured using laser diffraction (MALVERN MASTERSIZER S) with the powder dispersed in isopropanol. The slag has a vitreous phase content of $99 \%$ and a specific surface of $325 \mathrm{~m}^{2} / \mathrm{kg}$.

Tabla 3 / Table 3

Composición química de la escoria de horno alto. Chemical composition of blast furnace slag.

\begin{tabular}{|c|c|c|c|c|c|c|c|c|c|c|c|c|}
\hline$\%$ & $\mathrm{CaO}$ & $\mathrm{SiO}_{2}$ & $\mathrm{Al}_{2} \mathrm{O}_{3}$ & $\mathrm{MgO}$ & $\mathrm{Fe}_{2} \mathrm{O}_{3}$ & $\mathrm{SO}_{3}$ & $\begin{array}{c}\text { Sulfuros I } \\
\text { Sulfides }\end{array}$ & $\mathrm{Na}_{2} \mathrm{O}$ & $\mathrm{K}_{2} \mathrm{O}$ & $\begin{array}{c}\text { CaO libre I } \\
\text { free }\end{array}$ & L.O.I. & I.R. \\
\hline $\begin{array}{c}\text { Escoria de de } \\
\text { horno alto } \\
\text { / Blast } \\
\text { furnace } \\
\text { slag }\end{array}$ & 41.37 & 34.95 & 13.11 & 7.12 & 0.69 & 0.04 & 1.92 & 0.27 & 0.23 & - & 2.02 & 0.11 \\
\hline
\end{tabular}

L.O.I: pérdida al fuego / L.O.I.: loss on ignition. I.R. residuo insoluble / I.R.: insoluble residue.

a)

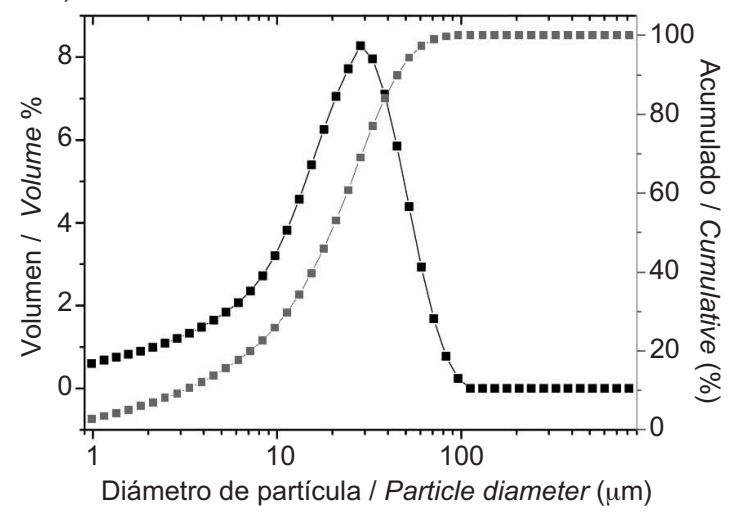

b)

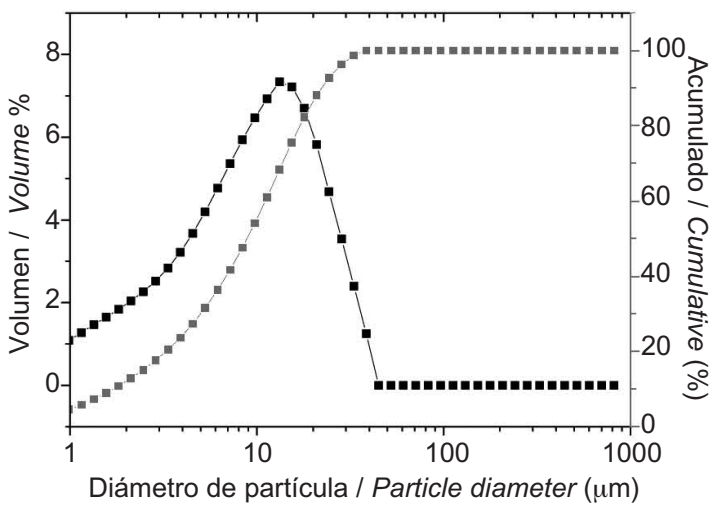

Figura 1. Distribución de partícula de (a) la escoria sin tamizar y (b) escoria tamizada por debajo de $20 \mu \mathrm{m}$ determinada mediante difracción láser y dispersada en isopropanol.

Figure 1. Particle size distribution of the (a) non- sieved slag and (b) sieved slag under $20 \mu \mathrm{m}$ measured by laser diffraction and dispersed in isopropanol. 


\subsubsection{Determinación del potencial zeta}

Se ha determinado el efecto de diferentes dosificaciones del aditivo PC sobre el potencial zeta de una suspensión de escoria en $\mathrm{NaOH}$ a $\mathrm{pH}=11,7$ utilizando el equipo AcoustosizerIIs (Colloidal Dynamics, North Attleboro, USA). Este ensayo no pudo realizarse en suspensiones de escoria con $\mathrm{pH}=13,6$, debido a que la extrema alcalinidad de la suspensión dañaba el equipo. Los potenciales zeta inducidos por los otros aditivos han sido previamente determinados y se pueden encontrar en la bibliografía (12). Las suspensiones de escoria se prepararon mezclando $40 \mathrm{~g}$ de escoria con un tamaño de particula inferior a $20 \mu \mathrm{m}$ (aproximadamente el límite superior que se puede utilizar para la determinación del potencial zeta usando la técnica electroacústica -ver Figura 1b) con $160 \mathrm{~g}$ de la disolución alcalina (fracción de sólidos $=0,222$ ). Las suspensiones se agitaron durante 15 minutos usando un agitador magnético. Después se aplicaron 5 minutos de ultrasonidos y posteriormente la mezcla se introdujo en la celda de medida. A estas suspensiones se añadieron automáticamente dosificaciones de aditivos entre 0 y $40 \mathrm{mg}$ polímero/g escoria. La contribución de la disolución de fondo fue corregida en los valores de potencial zeta obtenidos.

\subsection{Determinación del grosor de la capa de aditivo adsorbido}

El grosor de la capa de aditivo superplastificante adsorbido sobre las muestras $\alpha-\mathrm{Al}_{2} \mathrm{O}_{3}$ y escoria a $\mathrm{pH}=11,7$ y 13,6 se determinó mediante la técnica de Microscopía de Fuerzas Atómicas (21-25).

Debido a la elevada reactividad de los sistemas cementantes con agua es difícil obtener sustratos con una superficie lo suficientemente plana tal y como se requiere en la determinación de las curvas de fuerzas mediante AFM. Por esta razón, en el presente trabajo se han utilizado sustratos y sondas de $\alpha-\mathrm{Al}_{2} \mathrm{O}_{3}$ como un modelo inerte de la escoria. $\mathrm{A} \mathrm{pH}=10$, el potencial zeta de suspensiones de $\alpha-\mathrm{Al}_{2} \mathrm{O}_{3}$ es bajo y próximo a $-5 \mathrm{mV}$, siendo similar al potencial zetal de suspensiones de escoria (26). Utilizando este modelo se pueden obtener las curvas de fuerza sin interferencia de reacciones químicas y validar los resultados obtenidos para la escoria.

\subsubsection{Preparación de sustratos y sondas de AFM}

Sustratos. Se prepararon sustratos de $\alpha-\mathrm{Al}_{2} \mathrm{O}_{3}$ y escoria con un diámetro de $12 \mathrm{~mm}$ mediante sinterización Spark Plasma Sintering (SPS) (27). Los sustratos de $\alpha-\mathrm{Al}_{2} \mathrm{O}_{3}$ fueron sinterizados a $1.200{ }^{\circ} \mathrm{C}$ durante $5 \mathrm{~min}$. y a una presión de $100 \mathrm{MPa}$. Los sustratos de escoria se sinterizaron a $830{ }^{\circ} \mathrm{C}$ durante $5 \mathrm{~min}$. a $50 \mathrm{MPa}$. Finalmente todos los sustratos se pulieron con polvo de diamante de

\subsubsection{Determination of the zeta potential}

The effect of different dosages of the PC superplasticizer on the zeta potential of slag suspension in $\mathrm{NaOH}$ at $\mathrm{pH}=11.7$ was determined with an Acoustosizer IIs (Colloidal Dynamics, North Attleboro, USA). This test could not be conducted in slag suspensions using solutions of the higher $\mathrm{pH}(\mathrm{pH}=13.6)$ because the extreme alkalinity of the suspension would have damaged the instrument. The zeta potentials for the other superplasticizers have been previously determined and can be found elsewhere (12). Slag suspensions were prepared by mixing $40 \mathrm{~g}$ of slag having a particle size smaller than $20 \mu \mathrm{m}$ (approximately the upper size limit for zeta potential measurement using electro acoustics - see Figure $1 \mathrm{~b}$ ) with $160 \mathrm{~g}$ of alkaline solution (solid fraction in the suspension $=0.222$ ). Suspensions were stirred for 15 minutes in a magnetic stirrer. After 5 min sonication they were immediately placed in the measuring cell. Dosages ranging from 0 to $40 \mathrm{mg}$ solid polymer/g slag were automatically added to these suspensions. The zeta potential values were corrected for the pore solution background contribution.

\subsection{Determination of the adsorbed thickness layer}

The thickness of adsorbed layers of superplasticizers was determined for $\alpha-\mathrm{Al}_{2} \mathrm{O}_{3}$ samples and slag samples at $\mathrm{pH}=11.7$ and 13.6 using the colloidal probe AFM technique (21-25).

The high reactivity of cementitious systems in water makes it difficult to obtain substrates with the low surface roughness required for AFM force measurements in liquids. In the present study, $\alpha-\mathrm{Al}_{2} \mathrm{O}_{3}$ substrates and probes have been used as a non reactive model system for slag. At $\mathrm{pH}=10$ the zeta potential of $\alpha-\mathrm{Al}_{2} \mathrm{O}_{3}$ suspensions is low (around - $5 \mathrm{mV}$ ) and similar to slag suspensions (26). With this model, force curves can be recorded without the interference of chemical reactions and the findings for the blast furnace slag can be validated.

\subsubsection{AFM Substrates and probes preparation}

Substrates. $\alpha-\mathrm{Al}_{2} \mathrm{O}_{3}$ and slag substrates with a diameter of $12 \mathrm{~mm}$ were prepared by spark plasma sintering (SPS) (27). $\alpha-\mathrm{Al}_{2} \mathrm{O}_{3}$ substrates were sintered at $1200{ }^{\circ} \mathrm{C}$ for 5 min and at a pressure of $100 \mathrm{MPa}$. Slag substrates were sintered at $830^{\circ} \mathrm{C}$ for $5 \mathrm{~min}$ at $50 \mathrm{MPa}$. Both types of substrates were polished. The slag substrates were partially crystallized after sintering as observed by X-ray 


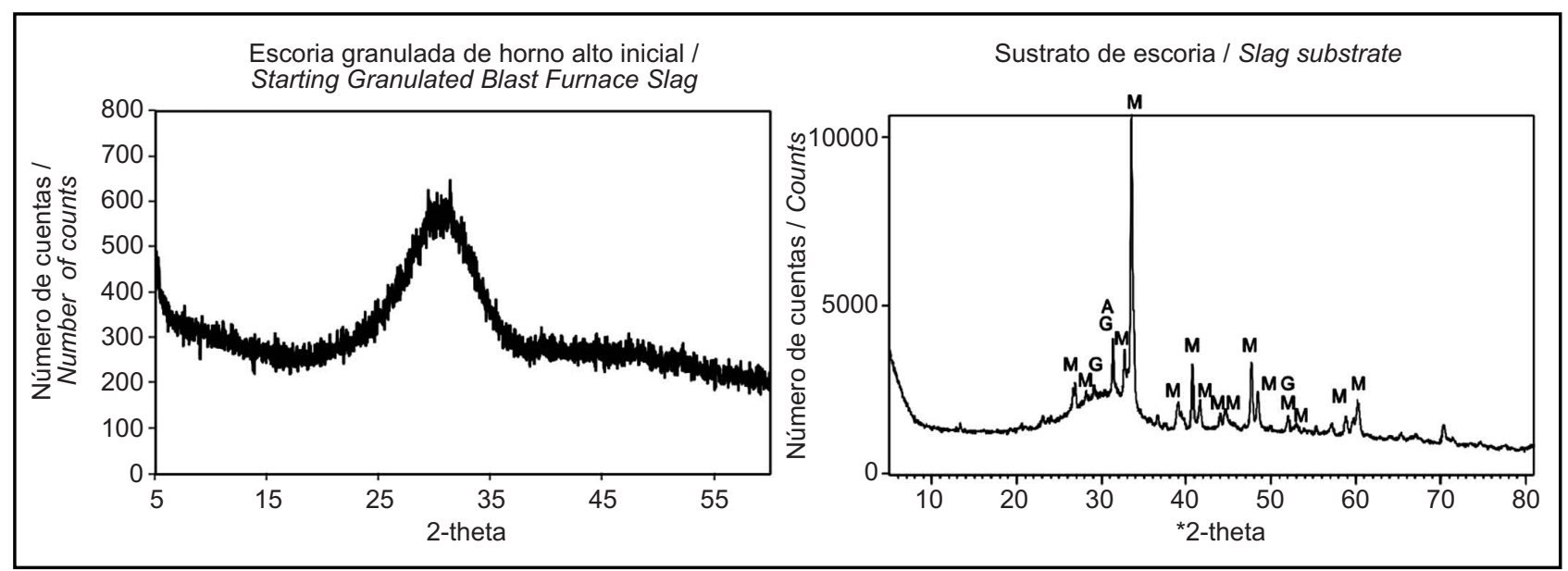

Figura 2. DRX de la escoria original y del sustrato de escoria obtenido mediante sinterización Spark Plasma (M = melilita, $\mathrm{A}=$ akermanita, $\mathrm{G}=$ gelenita).

Figure 2. XRD of the original slag and the slag substrate obtained by Spark Plasma Syntering $(M=$ melilite, $A=$ akermanite, $G=$ Gehlenite).

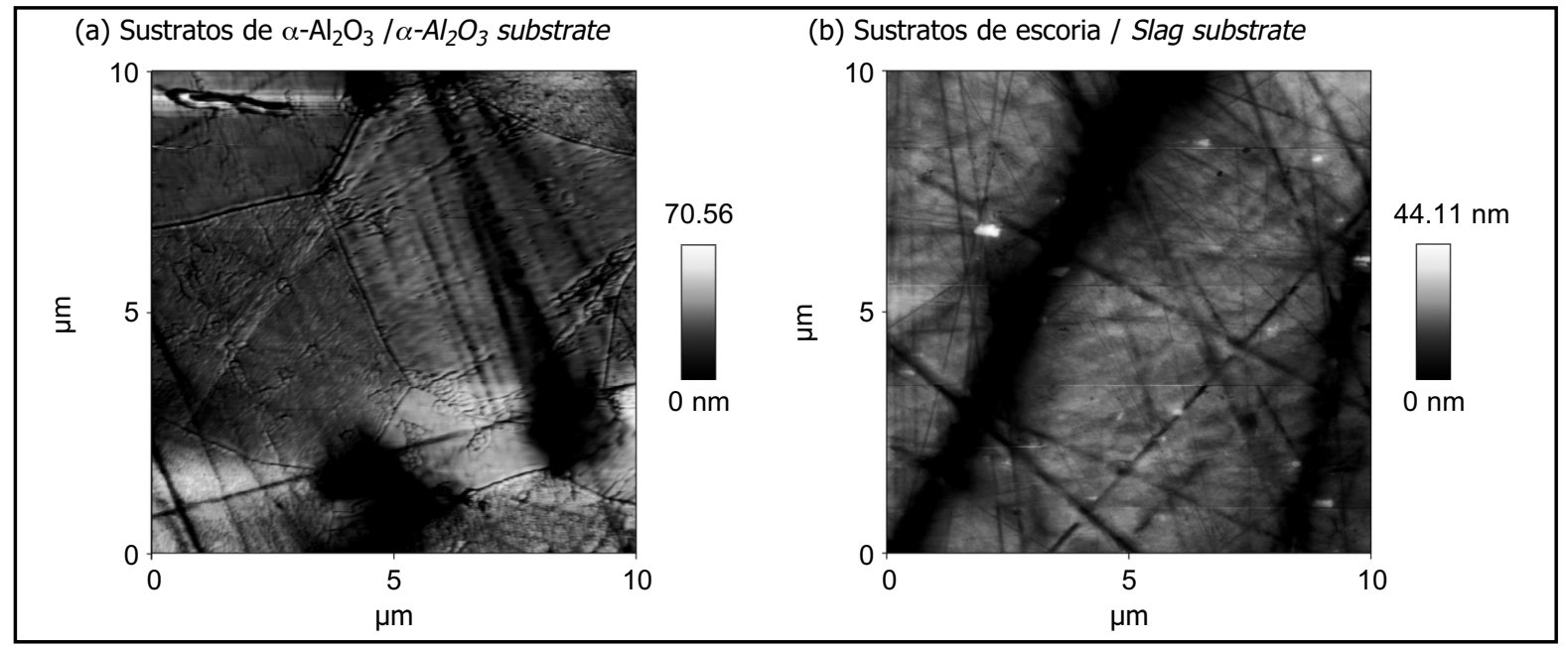

Figura 3. Imagen de AFM de sustratos de (a) $\alpha-\mathrm{Al}_{2} \mathrm{O}_{3}$ y (b) escoria. Escala de la imagen: $10 \mu \mathrm{m}$. Figure 3. AFM image of (a) $\alpha-\mathrm{Al}_{2} \mathrm{O}_{3}$ and (b) slag substrates. Image size: $10 \mu \mathrm{m}$.

$1 \mu \mathrm{m}$ hasta alcanzar una superficie especular. A través de difracción de rayos $X$ se comprobó que la escoria había cristalizado parcialmente (ver Figura 2). La Figura 3 muestra las imágenes de AFM de los sustratos de $\alpha-\mathrm{Al}_{2} \mathrm{O}_{3}$ y escoria.

Sondas de AFM. En la determinación de las curvas de fuerza en sistemas de $\alpha-\mathrm{Al}_{2} \mathrm{O}_{3}$ se ha utilizado como sonda partículas $\mathrm{AA}-18$ de $\alpha-\mathrm{Al}_{2} \mathrm{O}_{3}$ (Sumitomo Chemical Co., LTD) (Figura 4 (a)).

Para la determinación de las curvas de fuerza en sistemas de escoria activada con $\mathrm{NaOH}(\mathrm{pH}=11.7)$, se han utilizado como sondas partículas recristalizadas de escoria debido a su menor reactividad con respecto a la escoria vítrea (Figura 4b). Las partículas de escoria recristalizada se obtuvieron por tratamiento de la escoria a diffraction (see Figure 2). Figure 3 shows AFM images of the $\alpha-\mathrm{Al}_{2} \mathrm{O}_{3}$ and slag substrates.

AFM Probes. For the AFM force measurements carried out on $\alpha-\mathrm{Al}_{2} \mathrm{O}_{3}$ systems, $\alpha-\mathrm{Al}_{2} \mathrm{O}_{3} \mathrm{AA}-18$ particles (Sumitomo Chemical Co., LTD) were used as a probe (Figure 4 (a)).

For the AFM force measurements carried out on $\mathrm{pH} 11.7$ $\mathrm{NaOH}$ slag, recrystallized slag particles were used as slag probes due to their lower reactivity with respect to vitreous slag (Figure 4b). Recrystalized slag particles were obtained by treatment at $1000^{\circ} \mathrm{C}$ for 1 hour and subsequent quenching at room temperature. At 


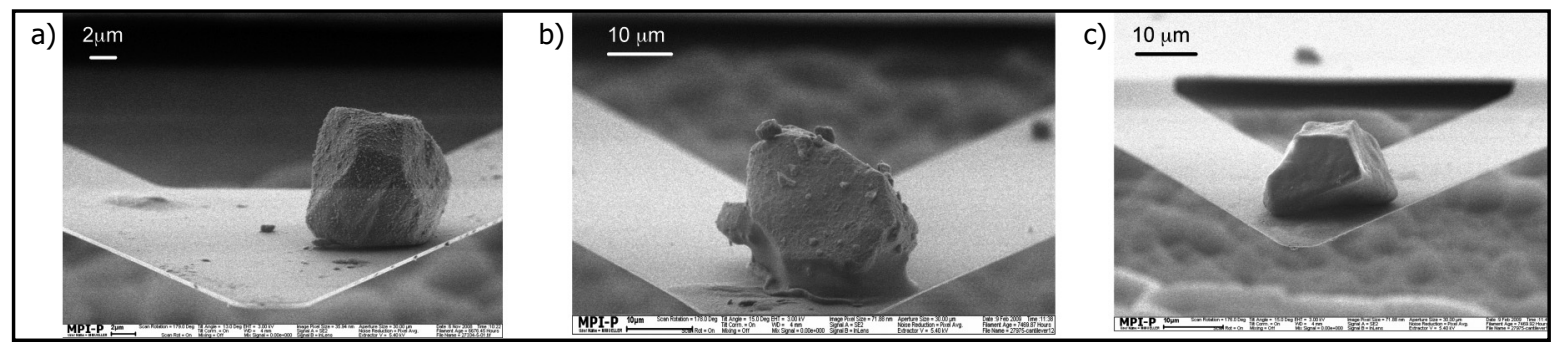

Figura 4. Imagen de microscopía electrónica de barrido de partículas de (a) $\alpha-\mathrm{Al}_{2} \mathrm{O}_{3}$, (b) escoria recristalizada y (c) MgO pegadas al cantilever. Figure 4. Scanning electron microscopic image of the (a) $\alpha-\mathrm{Al}_{2} \mathrm{O}_{3}$ (b) recrystalized slag and (c) MgO particles glued on the cantilever.

$1.000^{\circ} \mathrm{C}$ durante 1 hora y posterior enfriamiento rápido. A mayores $\mathrm{pH}, \mathrm{pH}=13,6$, las partículas de escoria recristalizada y $\alpha-\mathrm{Al}_{2} \mathrm{O}_{3}$ mostraron mayor reactividad. Por ello, en la determinación de las curvas de fuerza de la escoria en $\mathrm{NaOH} \mathrm{pH}=13,6$, se utilizaron como sondas partículas de MgO (Mag Chem P-98, Baltimor, U.S.A) (Figura $4 c)$. Trabajos previos $(8,24)$ han demostrado que a elevados $\mathrm{pH}$, el $\mathrm{MgO}$ puede utilizarse como modelo no reactivo del cemento. Todas las sondas utilizadas en el presente trabajo tienen un diámetro en el rango de 15-20 $\mu \mathrm{m}$ (Figura 4).

\subsubsection{Medidas de curvas de fuerza AFM}

La determinación de las curvas de fuerza se realizó utilizando un AFM (modelo JPK Nanowizard) mediante la técnica de la sonda de barrido. Las sondas se pegaron a cantilevers de nitruro de silicio en forma de $\mathrm{V}$ sin punta con la ayuda de un micro-manipulador (Figura 4). La constante de resorte del cantilever se determinó mediante el método de ruido térmico descrito en la bibliografía (21). Los valores de las constantes de resorte de los cantilever oscilaban entre 0,12 y $0,06 \mathrm{~N} / \mathrm{m}$ (cantilevers de nitruro de silicio NP, Veeco). Antes de cada medida, el cantilever se limpió con un plasma de argón durante 2 minutos a $30 \mathrm{~W}$ y 0,1-0,2 mbar para eliminar posibles contaminantes.

Las medidas de AFM se realizaron en disoluciones acuosas, utilizando una celda de líquidos. Se añadió $\mathrm{NaCl}$ 0,01 M a la disolución acuosa para apantallar parcialmente el potencial electrostático (28). Las disoluciones acousas utilizadas fueron:

a) Muestras de $\alpha-\mathrm{Al}_{2} \mathrm{O}_{3}$ :

$\mathrm{pH}=10,0:[\mathrm{NaOH}]=10^{-4} \mathrm{M}+[\mathrm{NaCl}]=0,01 \mathrm{M}$

b) Muestras de escoria:

b.1) $\mathrm{pH}=11,7:[\mathrm{NaOH}]=0,005 \mathrm{M}+[\mathrm{NaCl}]=0,01 \mathrm{M}$

b.2) $\mathrm{pH}=13,6:[\mathrm{NaOH}]=2,58 \mathrm{M}+[\mathrm{NaCl}]=0,01 \mathrm{M}$

Los aditivos superplastificantes se añadieron a la disolución acuosa en las siguientes concentraciones: $50 \mathrm{mg} / \mathrm{l}$ aditivo derivado de melamina, $50 \mathrm{mg} / \mathrm{l}$ aditivo derivado de naftaleno, 50mg/l aditivo copolímero vinílico y $25 \mathrm{mg} / \mathrm{l}$ aditivo basado en policarboxilato. Estas concentraciones
$\mathrm{pH}=13.6$, recrystalized slag and $\alpha-\mathrm{Al}_{2} \mathrm{O}_{3}$ particles show a high reactivity. To carry out AFM force measurements in 13.6- $\mathrm{pH} \mathrm{NaOH}$ slag samples, dead burnt MgO particles (Mag Chem P-98, Baltimor, U.S.A) were used as probes (Figure 4c). Previous papers $(8,24)$ have shown that at high alkaline $\mathrm{pH}$, dead burnt $\mathrm{MgO}$ can be used as a nonreactive model for cement. All probes used in the present study had a diameter in the range of 15-20 $\mu \mathrm{m}$ (Figure 4).

\subsubsection{AFM force measurements}

Force measurements were performed using an AFM (model JPK Nanowizard) using the colloidal probe technique. Probes were attached on V-shaped tipless silicon nitride cantilevers by using a micro manipulator and an epoxy resin as glue (Figure 4). The spring constant of the cantilever was measured using the thermal noise method according to a previously described technique (21). Spring constants of the cantilevers ranged from 0.12 to $0.06 \mathrm{~N} / \mathrm{m}$ (NP silicon nitride cantilevers, Veeco). Before each measurement, the cantilever was plasma cleaned in an Ar plasma for 2 minutes at $30 \mathrm{~W}$ and 0.10.2 mbar vacuum in order to remove contaminants.

The AFM measurements were carried out in aqueous solutions using a sealed liquid cell. $\mathrm{NaCl} 0.01 \mathrm{M}$ was added to the aqueous solution to partially screen the electrostatic potential (28). The aqueous solutions used were:

a) $\alpha-\mathrm{Al}_{2} \mathrm{O}_{3}$ samples: $p H=10.0:[\mathrm{NaOH}]=10^{-4} \mathrm{M}+[\mathrm{NaCl}]=0.01 \mathrm{M}$

b) slag samples:

b.1) $\mathrm{pH}=11.7:[\mathrm{NaOH}]=0.005 \mathrm{M}+[\mathrm{NaCl}]=0.01 \mathrm{M}$

b.2) $\mathrm{pH}=13.6:[\mathrm{NaOH}]=2.58 \mathrm{M}+[\mathrm{NaCl}]=0.01 \mathrm{M}$

Superplasticizers were added to the aqueous solution at a concentration of: $50 \mathrm{mg} / \mathrm{l}$ melamine-based admixture, 50mg/l naphthalene-based admixture, $50 \mathrm{mg} / \mathrm{l}$ vinyl copolymer admixture and $25 \mathrm{mg} / \mathrm{l}$ polycarboxylate-based admixture. These concentrations were higher than the 
son superiores al valor de la máxima cantidad de aditivo que la escoria es capaz de adsorber y fue determinado en anteriores trabajos (12). Previo a la determinación de las curvas de fuerza, el polímero se dejó 30 minutos en contacto con los sustratos para permitir su adsorción.

Las curvas de fuerza entre la sonda y el sustrato se determinaron mediante aproximación y alejamiento de ambas superficies, utilizando para ello el escáner piezoeléctrico del AFM. La velocidad de rastreo fue de $0,3 \mu \mathrm{m} / \mathrm{s}$ y la sonda y el sustrato estuvieron durante $1 \mathrm{~s}$ en contacto. Para cada muestra se determinaron 100 curvas de fuerza en 5 áreas diferentes de del sustrato, cada una de ellas de un área de $1 \mu \mathrm{m}^{2}$.

Las medidas de deflexión del cantilever se adquirieron en función del movimiento del escáner en la dirección Z. En este sistema, un láser se refleja sobre la parte trasera del cantilever hacia la posición de un detector de fotodiodos. La curva obtenida voltaje-diodo vs desplazamiento vertical del escáner se transformó en curvas de fuerzas vs. distancia (curvas de fuerza) mediante el método descrito en la bibliografía (29). Se realizó un ajuste lineal de la región de fuerza cero, es decir, la región donde la sonda y el sustrato están muy alejados, para restar cualquier desplazamiento del detector de voltaje, obteniendo de este modo un voltaje corregido $U_{P S D}$. La deflexión $D$ del cantilever en $\mathrm{nm}$ fue obtenida al multiplicar $U_{\mathrm{PSD}}$ por la sensitividad del sistema de detección óptico SPSD (ecuación [1]). El valor de $S_{P S D}$ se obtuvo por el ajuste lineal de la región donde la sonda y la superficie del sustrato están en contacto directo, de modo que la deflexión del cantilever es igual al movimiento del piezoeléctrico. La distancia sonda-muestra se obtiene restando la deflexión de la posición del piezo. Finalmente, la curva de fuerza se determina de la curva de deflexión utilizando la ley de Hooke (ecuación [2]). plateau values for the adsorption isotherms determined in prior studies (12) and led to full coverage of the particle surfaces. The polymer adsorption was carried out with a contact time of 30 minutes.

Surface forces between the probe and a flat substrate were evaluated by approaching and retracting the surfaces with the piezoelectric scanner of the AFM. The scan speed was $0.3 \mu \mathrm{m} / \mathrm{s}$ and the probe and the substrate were in contact for $1 \mathrm{~s}$. For each sample to assure representative statistics over 100 force measurements were carried out on 5 different spots within areas of $1 \mathrm{\mu m}^{2}$.

The deflection of the cantilever was recorded as a function of the movement of the scanner in the $Z$ direction using a laser beam, reflected from the backside of the cantilever onto a photodiode detector. Such diodevoltage vs. vertical scanner displacement curves were converted to force vs. distance curves (called force curves) by standard procedures (29). A linear fit of the zero force region, i.e. the region where probe and surface are a far apart, was used to subtract any offset of the detector voltage signal to obtain the corrected voltage signal $U_{P S D}$. The deflection $D$ of the cantilever in nanometers was obtained by multiplying $U_{P S D}$ by the sensitivity of the optical lever detection system $S_{P S D}$ (equation [1]). The value of $S_{P S D}$ is obtained from a linear fit of the constant compliance region, i.e. the region where probe and surface are in full contact and the cantilever deflection is equal to the piezo movement. The probe - sample distance is obtained by subtracting the deflection from the piezo position. Finally, the force curve is obtained from the deflection curve by using Hooke's law (equation [2]):

$$
\begin{gathered}
D=U_{P S D} \cdot S_{P S D} \\
F=-k \cdot D
\end{gathered}
$$

donde k es la constante de resorte del cantilever utilizado.

\subsection{Determinación de la constante de Hamaker de la escoria}

Se determinó la constante dieléctrica de una muestra de escoria densa (>99\%) sinterizada en un horno de Spark Plasma Sintering (SPS). A bajas frecuencias, se utlilizó un analizador impedancia/material E4991 ARF desde $1 \mathrm{MHz}$ a $1 \mathrm{GHz}$. No se encontró ninguna dispersión en este intervalo espectral. Para determinaciones a mayores frecuencias se eligieron medidas de reflectancia en el infrarrojo cercano. En este caso las constantes dieléctricas se determinaron en la ventana transparente entre 5.000 y $400 \mathrm{~nm}$. where $k$ is the spring constant of the cantilever used.

\subsection{Determination of slag Hamaker constant}

Dielectric constant measurements were carried out on dense (>99\%) powder compacts sintered by a spark plasma sintering (SPS). In the case of low frequency measurements, a E4991 ARF impedance/material analyzer was employed from $1 \mathrm{MHz}$ to $1 \mathrm{GHz}$. No dispersion was found in this spectral range. For high frequency measurements, near normal infrared reflectance measurements were chosen. In this case the dielectric constants were taken from the transparent window which extends from 5000 to $400 \mathrm{~nm}$. 
Con el objeto de comprobar que el proceso de sinterización no modificaba la naturaleza química de la muestra, se estudió tanto una muestra de escoria en polvo compactada a temperatura ambiente como una sinterizada a alta temperatura por SPS mediante reflectancia en el infrarrojo. Los detalles de la técnica, especialmente en lo referente al análisis de las muestras en polvo pueden consultarse en la referencia (30). La comparación entre ambos indicaba que no se observaban nuevos modos IR en la muestra preparada mediante SPS y consecuentemente el proceso por SPS no inducía ningún cambio en las propiedades de la muestra.

Conociendo las propiedades ópticas de la escoria (constante dieléctrica e índice de refracción), se puede determinar la constante efectiva de Hamaker como una función de la separación superficie-superficie, d, de acuerdo a la ecuación [3] (31).
In order to check that the sintering process did not modify the chemical nature of the powder, pressed powder samples were measured also by IR near normal reflectance (30). The comparison between them showed that no new IR mode appeared in the SPS sample, so that it can be concluded that no change in the dielectric properties of the sample is expected during the SPS process.

Knowing the optical properties (dielectric constant and refractive index) of the slag, the effective Hamaker constant as a function of the surface-surface separation $d$ was determined using equation [3] (31).

$$
A_{e f f}(d)=\frac{3}{4} k T\left(\frac{\varepsilon_{p}-\varepsilon_{m}}{\varepsilon_{p}+\varepsilon_{m}}\right)^{2}+\frac{3 \hbar \omega\left(n_{p}^{2}-n_{m}^{2}\right)^{2}}{16 \sqrt{2}\left(n_{p}^{2}+n_{m}^{2}\right)^{3 / 2}}\left\{1+\left[\frac{\pi n_{m}}{4 \sqrt{2}} \sqrt{n_{p}^{2}+n_{m}^{2}} \frac{d \omega}{c}\right]^{3 / 2}\right\}^{-2 / 3}
$$

Donde $\mathrm{k}$ es la constante de Boltzmann, $\mathrm{T}$ la temperatura, h la constante de Planck, c la velocidad de la luz y $\varepsilon$ y $\mathrm{n}$ la constante dieléctrica y el índice de refracción de las partículas de escoria (subíndice $p$ ) y del medio (subíndice $\mathrm{m}$ ), respectivamente. Además, $\omega$ es la frecuencia de absorción que, en este caso, se ha fijado en $2,01 \cdot 10^{16} \mathrm{~s}^{-1}$.

\subsection{Modelización de las fuerzas de dispersión mediante el software Hamaker}

Para estudiar las contribuciones relativas de las fuerzas atractivas y repulsivas que actúan sobre las partículas de escoria en suspensión, se realizó una modelización de las fuerzas entre partículas utilizando el programa Hamaker (32). Este software es fácil de utilizar para determinar fuerzas atractivas (van der Waals) y repulsivas (electrostáticas, estéricas). El software está escrito en Java y ha sido desarrollado para ser utilizado como una aplicación web de usuarios externos.

Se han considerado diferentes modelos para potenciales atractivos. Cada uno de estos modelos se aplicará de acuerdo al rango de tamaño de partícula (Hamaker no retardado: $10-100 \mathrm{~nm}$, Gregory: $1.000 \mathrm{~nm}$, Vincent: $10 \mathrm{~nm}$, Hamaker efectivo: mayor correspondencia en todo el rango de tamaños) (18). El programa incluye un módulo para calcular la barrera de potencial requerida para que cierta suspensión (caracterizada por concentración, densidad de partículas y medio) sea estable durante un tiempo definido. Una completa descripción del programa, su utilización y fundamento científico han
Where $k$ is the Boltzmann constant, $T$ the temperature, $h$ Planck's constant, $c$ the speed of light and $\varepsilon$ and $n$ are the dielectric constant and the refractive index of the slag particles (subscript $p$ ) and the medium (subscript $m$ ) respectively, $\omega$ is the absorption frequency, which has been fixed at $2.01 \cdot 10^{16} \mathrm{~s}^{-1}$ in the present case.

\subsection{Modelling of dispersion forces by Hamaker software}

To investigate the relative contributions of the different attractive and repulsive forces acting on the slag particles in suspension interparticle force modelling was carried out using the freeware Hamaker (32). This is a simple to use software for the key interparticles forces namely, attractive (van der Waals) and repulsive (electrostatic, steric). The software is written in Java and has been developed to be deployed as a web-start application for use by external users.

For the attractive potentials, different models have been implemented, each of which applies itself best to a certain size range (non retarded Hamaker: 10-100 nm, Gregory: $1000 \mathrm{~nm}$, Vincent: $10 \mathrm{~nm}$. Effective Hamaker: best correspondence over whole size range) (18). The program includes a module to calculate the potential barrier required for a certain suspension (characterized by: concentration, density of particles and medium) to be stable over a defined range of time. The software has a GUI for rapid plotting and a function to export the data into a spreadsheet. A complete documentation in the 
sido incluidos en una página web (18) y en una publicación (32).

En el caso del sistema de escoria, la distribución de tamaño de partícula fue determinada mediante difracción láser (Malvern Mastersizer, UK) obteniendo un valor de $\mathrm{D}_{\mathrm{v} 50}$ de 16.4 micras. La concentración iónica de la disolución de poro y la valencia nominal de la superficie negativamente cargada fueron estimadas en 0,025 M y 1,16 , respectivamente, de acuerdo al análisis químico de la disolución previamente publicado (33). Para determinar las fuerzas atractivas de van der Waals se utilizó el modelo efectivo Hamaker y para las repulsiones electrostáticas y estéricas, se utilizó el modelo clásico Hogg Healy Furstenau y el modelo simple de esferas impenetrables (hardwall model), respectivamente (32). En el caso de la repulsión electrostática el plano del potencial zeta fue colocado a la mitad o al final del grosor de la capa de aditivo adsorbido en el caso de aditivos sulfonados (34) ( $\mathrm{M}, \mathrm{NF}$ y $\mathrm{V}$ ) y a $1.0 \mathrm{~nm}$ para el aditivo basado en policarboxilato, cuya adsorción tiene lugar a través de la cadena hidrocarbonada principal cargada negativamente (8).

\subsection{Modelización del esfuerzo de cizalla umbral utilizando el modelo YODEL}

Flatt y Bowen $(17,35)$ han desarrollado un modelo de predicción del esfuerzo de cizalla umbral (YODEL) de suspensiones concentradas de partículas. Este modelo ha sido obtenido considerando las fuerzas entre partículas, la microestructura de la suspensión y la distribución del tamaño de las partículas, de modo que permite predecir el esfuerzo de cizalla umbral usando la siguiente ecuación [4]: form of an online-help, including the scientific background of each model, is included on the website and the recent publication $(18,32)$.

For the slag system the particle size distribution used was measured by laser diffraction (Malvern Mastersizer, UK) giving a $D_{\mathrm{v} 50}$ of $16.4 \mu \mathrm{m}$. The pore solution ionic concentration and nominal valence for negatively charged surface were estimated to be $0.025 \mathrm{M}$ and 1.16 respectively from pore solution chemical analysis and previously published methodology (33). For the attractive van der Waals forces the effective Hamaker model was used and for the electrostatic and steric, the classic Hogg Healy Furstenau and a simple hard wall model respectively (32). For the electrostatic repulsion the choice of the zeta potential plane was chosen to be at half or full adsorbed layer thickness for the sulphonated superplasticizers (34) and $1.0 \mathrm{~nm}$ for the poycarboxylate comb structured polymer where adsorption is expected to take place via the charged backbone (8).

\subsection{Modelling of the Yield stress using the YODEL model}

A model for yield stress prediction for concentrated particulate suspensions (YODEL) has been developed by Flatt and Bowen $(17,35)$. It was derived from first principles taking into account interparticle forces, suspension microstructure and particle size distributions. The model allows the prediction of the yield stress using the following equation [4]:

$$
\tau=m_{1} \frac{\phi\left(\phi-\phi_{0}\right)^{2}}{\phi_{\max }\left(\phi_{\max }-\phi\right)}
$$

Donde $\phi_{\max }$ es el máximo empaquetamiento de partículas totalmente dispersadas, $\phi_{0}$ es el límite de percolación y $\mathrm{m}_{1}$ es un prefactor que considera las fuerzas entre partículas, el tamaño de las partículas y la distribución de tamaño de partículas. El prefactor $m_{1}$ ha sido descrito asumiendo que los puntos de contacto entre las partículas tienen un valor medio y fijo de radio de curvatura*. Esto significa que las fuerzas no se escalan con el tamaño de partícula como en el caso de esferas lisas. En este caso, $\mathrm{m}_{1}$ puede escribirse de acuerdo a la ecuación [5]:

$$
m_{1}=\frac{1.8}{\pi^{4}} G_{\max } a * u_{k, k}\left(\frac{f_{\sigma, \Delta}^{*}}{R_{v, 50}^{2}}\right)
$$

Donde $\mathrm{G}_{\max }$ es la máxima fuerza atractiva entre partículas normalizada por el radio de curvatura de contacto. En
Where $\phi_{\max }$ is the maximum packing of well dispersed powders, $\phi_{0}$ is a percolation threshold and $m_{1}$ is a prefactor that accounts for interparticle forces, particle size, particle size distribution. The dependence of prefactor $m_{1}$, was best described when assuming that contact points among particles have an average fixed radius of curvature $a^{*}$. This implies that the forces do not scale with particle size as for smooth spheres. In this case, $m_{1}$ is written as [5]:

Where $G_{\text {max }}$ is the maximum attractive interparticle force normalized by the radius of curvature at the contact 
el caso de fuerzas atractivas de van der Waals con una constante de Hamaker $\mathrm{A}_{0}$ y una distancia mínima de separación $H, G_{\max }$ puede escribirse como (ecuación [6]): points. For van der Waals attraction with a Hamaker constant $A_{0}$ and a minimum separation distance $H$, this can be then written as [6]:

$$
G_{\max } \cong \frac{A_{0}}{12 H^{2}}
$$

El efecto de la distribución del tamaño de partícula es considerada en las funciones, $\mathrm{u}_{\mathrm{k}, \mathrm{k}}, \mathrm{f}_{\sigma, \Delta}^{*} \mathrm{y} \mathrm{R}_{\mathrm{v} 50, \mathrm{y} \text { ha sido }}$ descrito en detalle en la bibliografía (17).

\section{RESULTADOS Y DISCUSIÓN}

\subsection{Efecto de los aditivos superplastificantes sobre el potencial zeta de suspensiones de OPC y AAS}

En ausencia de aditivos superplastificantes, las suspensiones de escoria tienen un potencial zeta ligeramente negativo de -2,9 mV (Figura 5, Tabla 4). Sin embargo, y a pesar de este potencial superficial negativo, la escoria es capaz de adsorber el aditivo PC (aditivo aniónico). Estos resultados están de acuerdo con los obtenidos previamente por Nägele and Schneider (36), así como con nuestros trabajos previos (12).
The effect of the particle size distribution is taken into account by the functions, $u_{k, k} f_{o, \Delta}^{*}$ and $R_{v 50}$ and is described in more detail elsewhere (17).

\section{RESULTS AND DISCUSSION}

\subsection{Effect of the superplasticizers on the zeta potential of OPC and slag suspensions}

In absence of superplasticizers, slag suspensions have a slightly negative zeta potential of $-2.9 \mathrm{mV}$ (Figure 5, Table 4). Despite the negative surface potential the slag was observed to adsorb the anionic PC admixture. This agrees with results reported by Nägele and Schneider (36) and our previous work (12).

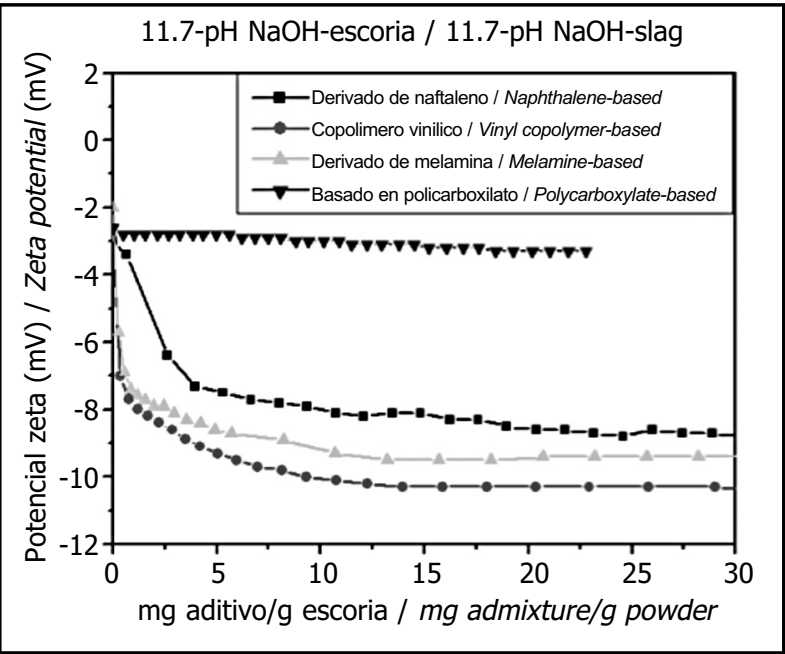

Figura 5. Potencial zeta de suspensiones de escoria en $\mathrm{NaOH}(\mathrm{pH}=11,7)$ en presencia de diferentes concentraciones de aditivos. Figure 5. Zeta potential of slag suspensions in $\mathrm{NaOH}(\mathrm{pH}=11.7)$ in the presence of different concentrations of admixtures.

Tabla 4 / Table 4

Valores plateau del potencial zeta en suspensiones de escoria en $\mathrm{NaOH}(\mathrm{pH}=11,7)$ en presencia de los aditivos superplastificantes ( \pm 0.06$)$. "Plateau" value of zeta potential of $\mathrm{pH} 11.7 \mathrm{NaOH}$ slag in presence of superplasticizers $( \pm 0.06)$.

\begin{tabular}{|c|c|c|c|c|c|}
\hline Suspensión / Suspension & Sin aditivo / Without admixture & NF & V & M & PC \\
\hline $\mathrm{pH} 11.7 \mathrm{NaOH}$ AAS & $-2.9 \mathrm{mV}$ & $-8.9 \mathrm{mV}$ & $-10.4 \mathrm{mV}$ & $-9.4 \mathrm{mV}$ & $-3.3 \mathrm{mV}$ \\
\hline
\end{tabular}


Los aditivos sulfonados ( $\mathrm{NF}, \mathrm{V}$ y $\mathrm{M})$ inducen potenciales zeta en el rango entre -9 y $-11 \mathrm{mV}$. El incremento del potencial zeta inducido por estos aditivos superplastificantes indica que la repulsión electrostática podría estar involucrada en el mecanismo de repulsión que inducen.

Los aditivos basados en policarboxilato solo disminuyen muy ligeramente el potencial zeta de las suspensiones de AAS y OPC, lo que indica que para este tipo de aditivos la repulsión electrostática que inducen es despreciable $(6,8,28,37)$.

\subsection{Determinación de la capa de aditivo adsorbido mediante microscopía de fuerzas atómicas (AFM)}

En sistemas de alúmina se observa que las curvas de fuerza de aproximación y retracción de las superficies son muy diferentes (ver Figura 6). Cuando el sustrato y la sonda de alúmina se aproximan se detectan fuerzas repulsivas a cortas distancias. Cuando se aproximan más ambas superficies, se vence esta repulsión y las superficies entran en contacto (38). Al separarse, se observa una elevada adhesión entre las superficies que conduce a una deflexión negativa del cantilever. La repulsión que se observa al aproximarse la sonda y el sustrato de alúmina es debida a una combinación de repulsión electrostática y a la existencia de posibles capas de alúmina hidratada. La adhesión en la retracción es debida a las fuerzas de atracción de van der Waals entre las superficies de alúmina (28).

Las curvas de fuerza de los sistemas de escoria a $\mathrm{pH}=11,7$ son similares a las de los sistemas de $\alpha-\mathrm{Al}_{2} \mathrm{O}_{3}$, con una fuerza de adhesión de similar magnitud (Figura 6b), sin embargo, los sistemas de escoria a $\mathrm{pH}=13,6$ presentan comportamientos significativamente diferentes (Figura 6c). Al aproximarse la partícula de $\mathrm{MgO}$ al sustrato de escoria se observa una repulsión entre ambas superficies a aproximadamente $40 \mathrm{~nm}$ que se incrementa linealmente. Esto es una indicación de la formación de una capa blanda que es deformada plásticamente por la punta del cantilever. En la curva de separación también se observa una repulsión, siendo su pendiente superior que en el caso de la curva de aproximación de ambas superficies. Esta histeresis está relacionada con el grado de deformación plástica.

Nuevamente, se observa una elevada adhesión entre las superficies cuando éstas se separan. De hecho, estas fuerzas atractivas se detectan incluso hasta distancias de $90 \mathrm{~nm}$ lo que sugiere que se ha formado un nuevo material que impide a la punta del cantilever entrar en contacto con la superficie del sustrato. En otras palabras,
The admixtures containing sulfonic groups (a naphthalene derivative, a vinyl copolymer and a melamine derivative) shifted the zeta potential to values between -9 to $-11 \mathrm{mV}$. The increased negative zeta potential induced by these superplasticizer indicates that electrostatic repulsion may play a role in the dispersion mechanism.

For the polycarboxylate admixtures in these slag suspensions the zeta potential decreased only slightly indicating that as for OPC suspensions, the electrostatic repulsion induced by this type of admixtures is expected to be negligible $(6,8,28,37)$.

\subsection{Determination of the adsorbed layer thickness of the admixtures by colloidal probe atomic force microscopy}

When measuring the force between an alumina probe and an alumina substrate the force-distance curves differ between the approach and the separation (Figure 6). On approach a repulsive force was measured at short distances. By approaching further, the repulsion is finally overcome until both surfaces are in contact (38). Upon separation a marked adhesion between the surfaces is observed which leads to a negative deflection of the cantilever and a snap off at the point where the restoring force of the cantilever overcomes the attractive force. The repulsion in approach is most likely due to a combination of electrostatic repulsion and surface hydration layers. The adhesion in retraction is attributed to the expected van der Waals forces between the alumina surfaces (28).

Force curves of slag systems at $\mathrm{pH}=11.7$ show a similar profile to the $\alpha-\mathrm{Al}_{2} \mathrm{O}_{3}$ systems, with a similar magnitude of the adhesion force (Figure 6b). Force curves determined in slag systems at $\mathrm{pH}=13.6$ are significantly different (Figure 6c). On approach an apparent repulsion between the $\mathrm{MgO}$ and slag surfaces was observed. It ranged out to $40 \mathrm{~nm}$ and increased linearly. We take this as an indication that a soft layer has formed which is plastically deformed by the tip. This is supported by the fact that upon retraction the tip follows a steeper curve. The hysteresis, that is the difference between approach and retraction at a given force, indicates the degree of plastic deformation.

Upon separation also a high adhesion is observed. In contrast to the other two cases this is not pure contact adhesion. The attractive force ranges out to an apparent distance around $90 \mathrm{~nm}$. This indicates that a bridge of material is formed which prevents the tip from losing contact. From these results we deduce that the slag 

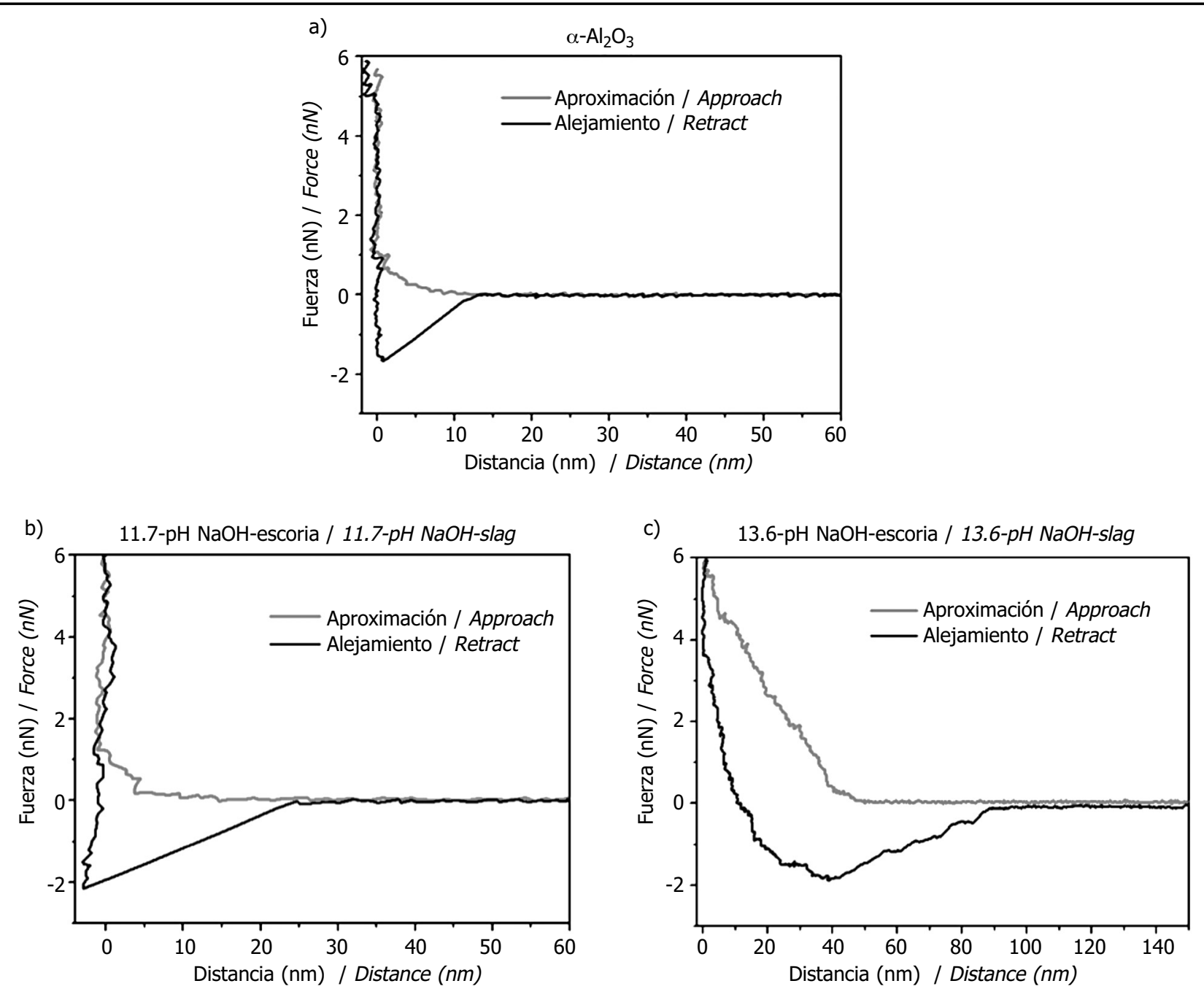

Figura 6. Curvas típicas de fuerza-distancia en ausencia de aditivos entre (a) superficies de alumina, (b) superficies de escoria $(\mathrm{pH}=11,7)$ y (c) superficies de $\mathrm{MgO}$ y escoria $(\mathrm{pH}=13,6)$.

Figure 6. Typical force-versus-distance curves in absence of superplasticizer between (a) alumina surfaces, (b) slag surfaces (pH=11.7) and (c) MgO and slag surfaces ( $\mathrm{pH}=13.6)$.

el sustrato de escoria parece estar reaccionando en estos medios tan fuertemente alcalinos a pesar de que el proceso de sintéresis había recristalizado parcialmente la escoria y que el sustrato presentaba elevada densidad. Consecuentemente, las curvas de fuerza obtenidas a $\mathrm{pH}=13,6$ deben de ser descartadas descartadas para el cálculo del grosor de la capa de aditivo adsorbido.

Las Figuras 7, 8 y 9 muestran las curvas de separación para los sistemas de $\alpha-\mathrm{Al}_{2} \mathrm{O}_{3}$ y escoria en $\mathrm{NaOH} \mathrm{pH}=11,7$ y en presencia de los cuatro superplastificantes. En todos los casos, las curvas muestran una repulsión a distancias cortas de la superficie, no detectándose adhesión. Esto indica que el polímero adsorbido previene el contacto directo de ambas superficies en estas condiciones. De acuerdo con Pedersen y Bergström (28), en las curvas de fuerza en presencia de polielectrolitos aniónicos se pueden detectar dos regiones diferentes: a largas distancias, en donde se substrate is reacting in these highly alkaline conditions despite the fact that after the sintering process it is partially recrystalised and has a high density. Consequently, the force curves obtained at $\mathrm{pH}=13.6$ could not be evaluated with respect to determining the thickness of adsorbed polymer layers.

Figures 7, 8 and 9 show the separation curves determined for $\alpha-\mathrm{Al}_{2} \mathrm{O}_{3}$ and $\mathrm{pH} 11.7 \mathrm{NaOH}$ slag systems in presence of the four superplasticizers. In all cases, the curves are short-range repulsive and no adhesion was observed, indicating the adsorbed polymer layer prevents direct contact under these experimental conditions. According to Pedersen and Bergström (28) the force-distance curves in the presence of anionic polyelectrolyte can be divided in two different regions. $A$ long-distance tail is of electrostatic origin while at closer 


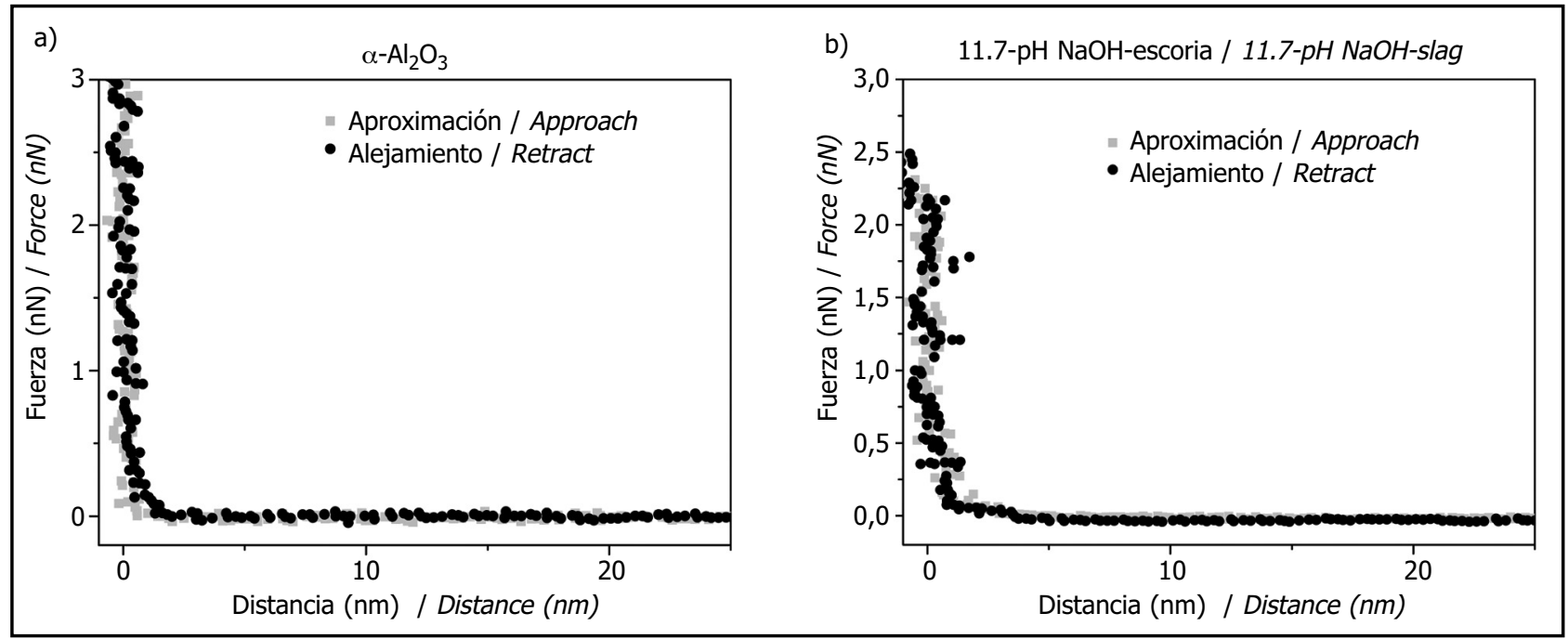

Figura 7. Curvas de fuerza en presencia de $50 \mathrm{mg} / \mathrm{l}$ aditivo derivado de naftaleno en (a) superficies de alumina, (b) superficies de escoria $(\mathrm{pH}=11,7)$.

Figure 7. Typical force curves in presence of $50 \mathrm{mg} / \mathrm{l}$ naphthalene admixture of (a) alumina surfaces, (b) slag surfaces ( $\mathrm{pH=11.7).}$

observa una cola debida a una repulsión de tipo electrostática y a distancias cortas, para las que la repulsión tiene origen estérico. Sin embargo, debido a la relativamente elevada fuerza iónica a la que estamos trabajando $(0,01$ $\mathrm{M} \mathrm{NaCl}$ ), la repulsión electrostática está apantallada a largas distancias de modo que la máxima repulsión observada en las curvas de fuerza puede ser atribuida a una repulsión estérica (28). Los autores del presente trabajo no hemos intentado cuantificar las fuerzas de repulsión estérica, porque es probable que todavía pueda quedar una pequeña contribución electrostática a distancias cortas. Sin embargo, el rango de repulsión estérica y consecuentemente el máximo grosor de la capa de aditivo adsorbido se ha podido determinar a partir de la curva de retracción, concretamente a partir de la distancia de desaparición de las fuerzas de repulsión que es dos veces el grosor de la capa de polielectrolito adsorbido $\left(L_{\text {ads }}\right)[7]$ : distance the repulsion is of steric origin. However, at relatively high ionic strength $(0.01 \mathrm{M} \mathrm{NaCl})$, the electrostatic repulsion is screened at long distances and the maximum repulsion range observed in the forcedistance curve can be attributed to steric repulsion (28). We have not tried to quantify the steric repulsion force as there is probably still a small electrostatic contribution at short distances. The onset of the repulsive force in the retraction part of the force curves was therefore taken as the upper limit of the steric repulsion range to estimate the maximum adsorbed layer thickness. Consequently, the polyelectrolyte adsorbed layer thickness ( $\left.L_{\text {ads }}\right)$ was estimated using equation [7] from the steric repulsion range $(D)$ determined in the force curves.

$$
\mathrm{D}=2 \mathrm{~L}_{\mathrm{ads}}
$$

En la Tabla 5 se muestran los rangos de repulsión estérica inducida por los diferentes aditivos superplastificantes, determinados a partir de las curvas de fuerza. Estos rangos de repulsión estérica son los valores medios calculados a partir de 70-250 curvas. La desviación estándar de estas medidas refleja la elevada dispersión de las medidas debido a la dificultad de obtener estas curvas de fuerza con tan pequeños grosores de aditivo adsorbido (Tabla 5). Los rangos de repulsión estérica son muy similares en sistemas de alúmina y de escoria $(\mathrm{pH}=11,7)$, lo que indica que la alúmina es un buen modelo no reactivo de la escoria a este $\mathrm{pH}$.
Table 5 gives the range of steric repulsion attributed to the superplasticizer admixtures, calculated from the force-distance curves. The steric repulsion ranges are average values calculated from between 70 to 250 force curve measurements. The standard deviations of these measurements give an indication of the broad spread of the measurements highlighting the difficulty to get accurate figures for such small adsorption layer thicknesses (Table 5). As these steric repulsion ranges were very similar for both the alumina and slag $(\mathrm{pH}=11.7)$ systems, alumina was concluded to be a very good non-reactive model for blast furnace slag under these mild alkaline conditions. 


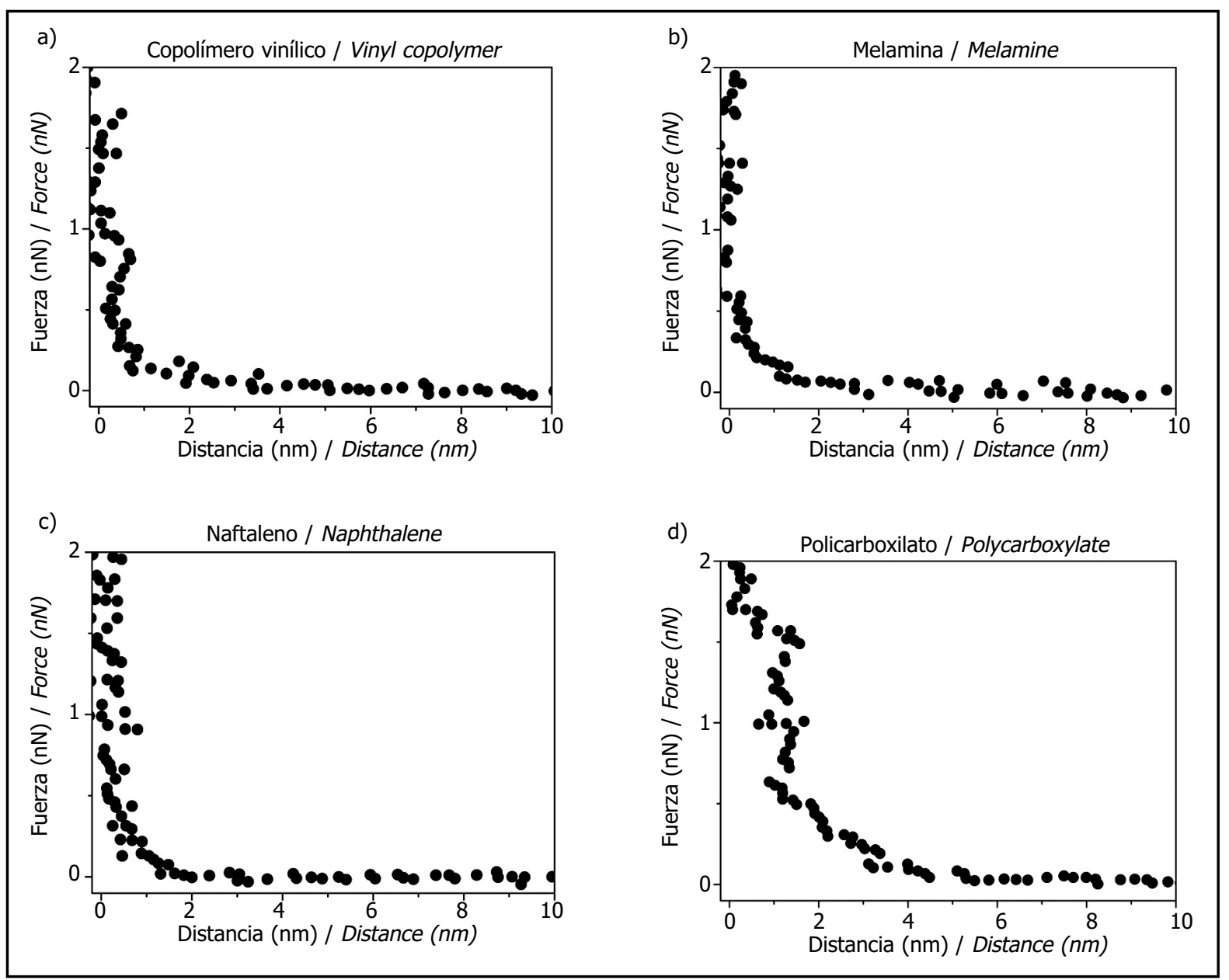

Figura 8. Curvas de fuerza típicas de retracción entre superficies de alúmina en presencia de (a) $50 \mathrm{mg} / \mathrm{l}$ aditivo copolímero vinílico, (b) $50 \mathrm{mg} / \mathrm{l}$ aditivo derivado de melamina, (c) $50 \mathrm{mg} / \mathrm{l}$ aditivo derivado de naftaleno y (d) $25 \mathrm{mg} / \mathrm{l}$ aditivo basado en policarboxilato.

Figure 8. Typical retraction force curves between alumina surfaces in presence of (a) $50 \mathrm{mg} / \mathrm{l}$ vinyl copolymer admixture, (b) $50 \mathrm{mg} / \mathrm{l}$ melamine-based admixture, (c) $50 \mathrm{mg} / \mathrm{l}$ naphthalene admixture and (d) $25 \mathrm{mg} / \mathrm{l}$ polycarboxylate-based admixture.

Tabla 5 / Table 5

Rango de repulsión estérica y grosor de la capa de aditivo adsorbido inducido por los aditivos superplastificantes ( \pm es la desviación estándar).

Steric repulsion range and adsorbed layer thickness induced by the superplasticizers ( \pm is the standard deviation from the number of force curves measured).

\begin{tabular}{|c|c|c|c|c|c|}
\hline & & $50 \mathrm{mg} / \mathrm{l} \mathrm{NF}$ & $50 \mathrm{mg} / \mathrm{l} \mathrm{V}$ & $50 \mathrm{mg} / \mathrm{l} \mathrm{M}$ & $25 \mathrm{mg} / \mathrm{l} \mathrm{PC}$ \\
\hline \multirow{3}{*}{$\alpha-\mathrm{Al}_{2} \mathrm{O}_{3}$} & $\begin{array}{l}\text { Rango de repulsión estérica / } \\
\text { Steric repulsion range }(\mathrm{nm})\end{array}$ & $1.9 \pm 0.7$ & $3.9 \pm 1.0$ & $3.3 \pm 1.2$ & $4.4 \pm 1.4$ \\
\hline & $\begin{array}{c}\text { Grosor de la capa de aditivo / } \\
\text { Layer thickness }(\mathrm{nm})\end{array}$ & $1.0 \pm 0.3$ & $2.0 \pm 0.5$ & $1.6 \pm 0.6$ & $2.2 \pm 0.7$ \\
\hline & $\begin{array}{l}\text { Número de curvas de fuerza / } \\
\text { Number of force curves }\end{array}$ & 208 & 74 & 136 & 264 \\
\hline \multirow{3}{*}{$\begin{array}{c}\text { Escoria activada } \\
\text { con } \mathrm{NaOH} / \\
11.7-p H ~ N a O H \\
\text { slag } p H=11.7\end{array}$} & $\begin{array}{l}\text { Rango de repulsión estérica / } \\
\text { Steric repulsion range }(\mathrm{nm})\end{array}$ & $2.6 \pm 1.0$ & $3.5 \pm 1.0$ & $3.1 \pm 1.3$ & $5.1 \pm 1.6$ \\
\hline & $\begin{array}{c}\text { Grosor de la capa de aditivo / } \\
\text { Layer thickness }(\mathrm{nm})\end{array}$ & $1.3 \pm 0.5$ & $1.8 \pm 0.5$ & $1.5 \pm 0.6$ & $2.5 \pm 0.8$ \\
\hline & $\begin{array}{l}\text { Número de curvas de fuerza / } \\
\text { Number of force curves }\end{array}$ & 87 & 254 & 113 & 141 \\
\hline
\end{tabular}




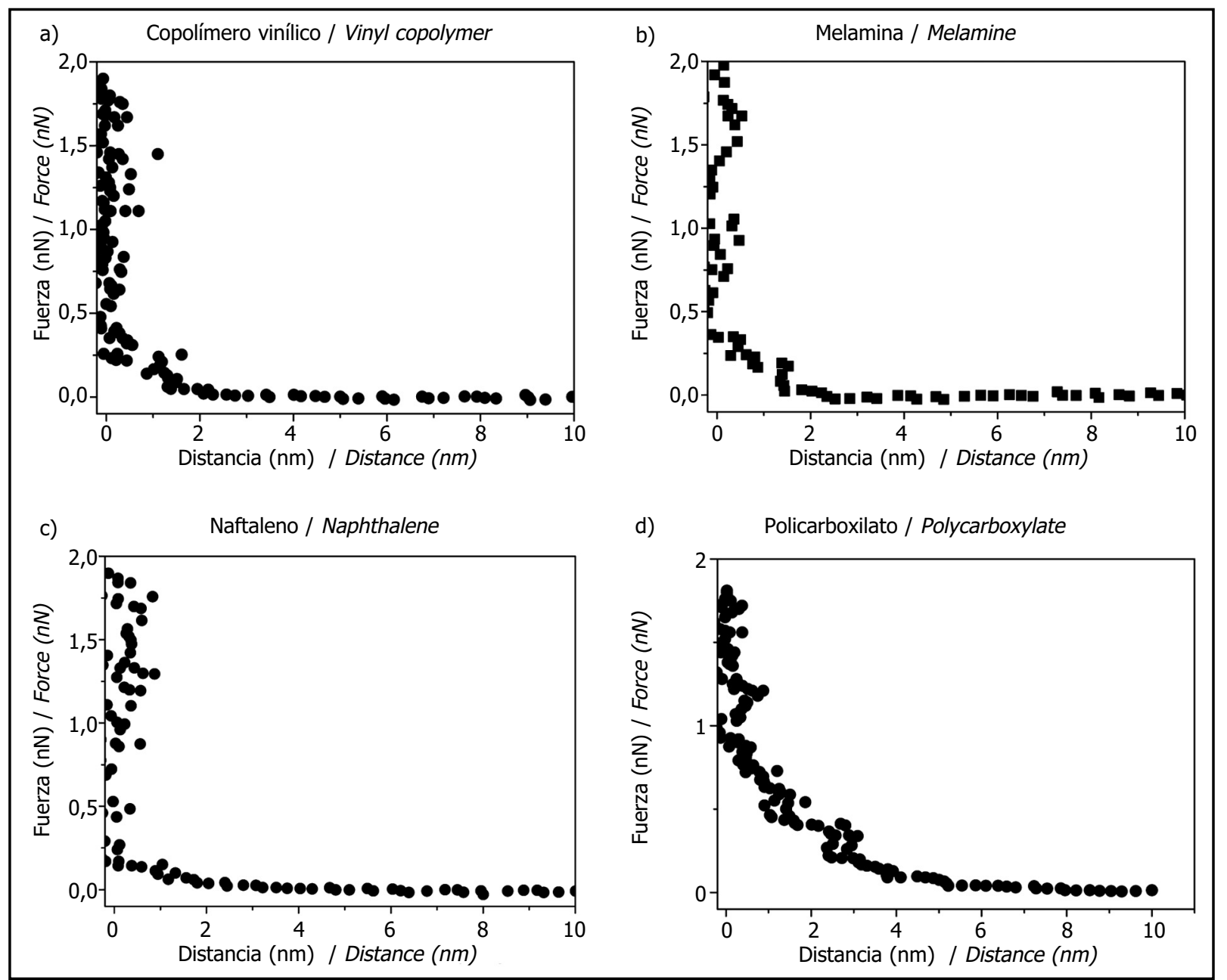

Figura 9. Curvas típicas de fuerzas de retracción entre superficies de escoria $(\mathrm{pH}=11,7)$ en presencia de (a) $50 \mathrm{mg} / \mathrm{l}$ aditivo copolímero vinílico,

(b) $50 \mathrm{mg} / \mathrm{l}$ aditivo derivado de melamina, (c) $50 \mathrm{mg} / \mathrm{l}$ aditivo derivado de naftaleno y (d) $25 \mathrm{mg} / \mathrm{l}$ aditivo basado en policarboxilato. Figure 9. Typical retraction force curves between slag surfaces in presence of (a) $50 \mathrm{mg} / \mathrm{l}$ vinyl copolymer admixture,

(b) $50 \mathrm{mg} / \mathrm{l}$ melamine-based admixture, (c) $50 \mathrm{mg} / \mathrm{l}$ naphthalene admixture and (d) $25 \mathrm{mg} / \mathrm{l}$ polycarboxylate-based admixture.

Tanto en sistemas de escoria como de alúmina, el aditivo derivado de naftaleno con el menor peso molecular (ver Tabla 2) induce un menor rango de repulsión estérica. Por el contrario, el aditivo basado en policarboxilato, a pesar de tener un menor peso molecular que los aditivos derivados de la melamina y del copolímero vinílico, presenta el mayor rango de repulsión estérica y consecuentemente el mayor grosor de capa de aditivo adsorbido. Esto puede deberse a la diferente conformación de estos aditivos al adsorberse, lo que está relacionado con su diferente estructura molecular (5). En este trabajo no hemos analizado la conformación de estos aditivos porque requiere de una caracterización más detallada de las estructuras moleculares de los aditivos comerciales, que no se ha realizado en este estudio.

Como se ha indicado anteriormente, la repulsión de los aditivos superplastificantes inducida en sistemas de AAS a $\mathrm{pH}=13,6$ y el grosor de la capa de aditivo adsorbida no
Both in the non-reactive alumina model and the slag system, the range of steric repulsion was the smallest with the naphthalene derivative admixture, the admixture with the lowest molecular weight (see Table 2). The polycarboxylate-based admixture, by contrast, induced highest steric repulsion and consequently a thicker layer of adsorbed admixture, even though it had a lower molecular weight than the melamine derivative and the vinyl copolymer. This is presumably due to different adsorption conformations of these polymers related to their different molecular structures (5) but further analysis is beyond the scope of the current investigation with commercial admixtures where detailed molecular structures have not been determined.

As noted above, neither the steric repulsion generated by the superplasticizers in slag in a $\mathrm{pH} 13.6 \mathrm{NaOH}$ solution nor the thickness of the layer of adsorbed 
ha podido ser determinada como consecuencia de la elevada reactividad de la escoria en estas condiciones. Sin embargo, en base a los ensayos reológicos realizados en estudios previos $(12,13)$, se podría esperar una significativa disminución de la repulsión inducida por los aditivos derivados de melamina, copolímero vinílico y basado en policarboxilato, debido a su inestabilidad química en estos medios tan fuertemente alcalinos (16). Por el contrario, el aditivo derivado de naftaleno (estable a $\mathrm{pH}=13,6)(15,16)$ origina similares descensos del esfuerzo de cizalla umbral en sistemas de escoria activada alcalinamente a $\mathrm{pH}=11,7$ y a $\mathrm{pH}=13,6$, lo que indicaría que la repulsión estérica inducida por este aditivo en ambos sistemas sería similar (12). Esta hipótesis se confirmará en futuros estudios.

\subsection{Determinación de la constante de Hamaker de la escoria}

La Figura 10 muestra los valores de la constante dieléctrica en función en función del número de onda para la escoria sinterizada. Utilizando estos datos ópticos de la escoria sinterizada se ha calculado la constante de Hamaker a partir de la ecuación [3]. Los valores obtenidos son función de la separación superficie-superficie, tal y como se muestra en la Figura 11. La constante de Hamaker presenta un pequeño "plateau" a distancias cortas, seguida de una rápida caída y final convergencia a mayores separaciones. Debido a la concentración iónica de la disolución en los poros de la escoria (33) $(0,025 \mathrm{M})$, el término estático de la constante de Hamaker está completamente apantallado a distancias $>1,5 \mathrm{~nm}$. Por lo tanto, se espera que los valores en la región visible del

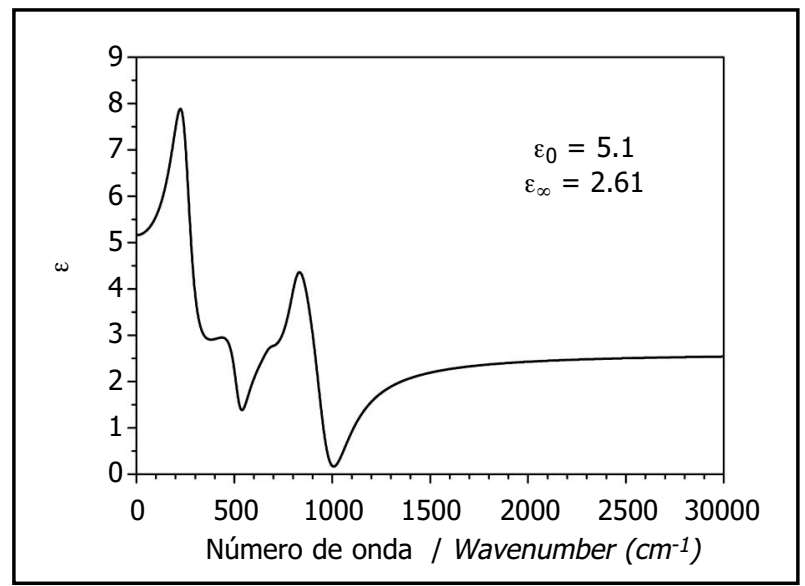

Figura 10. Espectro de constante dieléctrica IR en función del número de onda en escoria sinterizada. Nótese que la región plana, sin dispersión a partir de $1.500 \mathrm{~cm}^{-1}$ se extiende prácticamente invariable por toda la zona del espectro visible, hasta $400 \mathrm{~nm}$ o $25.000 \mathrm{~cm}^{-1}$

Figure 10. Spectrum of the dielectric constant IR as a function of wavenumber for the sintered slag. Note that the flat region, without dispersion from $1500 \mathrm{~cm}^{-1}$ stays practically constant in the visible area up to $400 \mathrm{~nm}$ or $25000 \mathrm{~cm}^{-1}$. admixture could be determined due to the high reactivity of slag under these conditions. Nonetheless, based on the rheological trials conducted in previous studies (12, 13), repulsion would be expected to be significantly reduced in melamine derivative, vinyl copolymer and polycarboxylate admixtures as a result of their chemical instability in highly alkaline media as previous studies have shown (16). By contrast, the decline in the shear force induced by the naphthalene derivative admixture (stable in $\mathrm{NaOH}(\mathrm{pH}=13.6)(15,16)$ ) in $\mathrm{pH} 13.6 \mathrm{NaOH}$ AAS pastes was similar to the decrease generated in $\mathrm{pH}$ 11.7 NaOH AAS pastes, an indication that steric repulsion was similar in the two systems (12). This hypothesis will have to be confirmed by further studies.

\subsection{Determination of slag Hamaker constant}

The results from the dielectric property measurements showing the dielectric constant as a function of as a function of wavenumber for the sintered slag are shown in Figure 10. Based on this optical data the Hamaker constant has been calculated using equation 3. The obtained values as a function of the surface-surface separation are shown in Figure 11. The Hamaker constant has the normal form of a small plateau at short separations followed by a rapid drop and finally convergence at large separations. Because of the electrolyte concentration found in slag pore solutions (33) (0.025 M) the static term of the Hamaker constant is completely screened at distances $>1.5 \mathrm{~nm}$. Therefore values in the visible region are expected to give the most suitable Hamaker constants

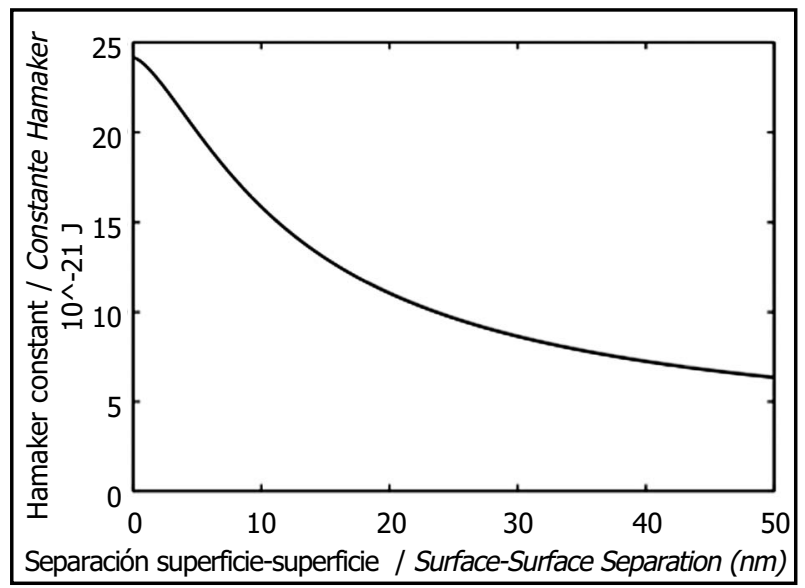

Figura 11. Constante efectiva de Hamaker en función de la separación entre partículas para la escoria sinterizada utilizando el software Hamaker (18).

Figure 11. Effective Hamaker constant as a function of particle surface separation for sintered blast furnace slag using the Hamaker software (18). 
espectro sean los más adecuados para determinar la constante de Hamaker y es por ello que fueron utilizados en el cálculo de las interacciones entre partículas. Estos valores son coherentes con la constante de Hamaker determinada por Flatt (19) utilizando un método de escalamiento (scaling methods) de diferentes fases minerales.

\subsection{Modelización de las fuerzas de dispersión mediante el programa Hamaker}

Utilizando el programa de Hamaker (18) se determinaron las curvas de potencial entre partículas en función de su distancia. Para el aditivo PC, la repulsión electrostática es despreciable y la energía potencial de interacción total (VT) es la suma de la energía potencial de van der Waals $\left(\mathrm{V}_{\mathrm{vdw}}\right)$ y la repulsión estérica de acuerdo a la ecuación [8]:

and were therefore used in the interparticle interaction calculations. These values are coherent with Hamaker constants evaluated by Flatt (19) using a scaling approach for several different mineral phases.

\subsection{Modelling of dispersion forces by Hamaker software}

Interparticle potential curves as a function of particle surface separation were calculated for the blast furnace slag using the Hamaker software (18). For PC the electrostatic repulsion is negligible and the total interaction potential energy (VT) is the sum of the van der Waals $\left(V_{v d w}\right)$ potential energy and steric hindrance $\left(V_{\text {steric }}\right)$ as given by [8]:

$$
\mathrm{V}_{\mathrm{T}}=\mathrm{V}_{\mathrm{vdw}}+\mathrm{V}_{\text {steric }}
$$

Para NF, V y M, la energía potencial de interacción total ha sido calculada utilizando dos modelos: (a) considerando la repulsión electrostática despreciable (Ecuación [8]) y (b) considerando dicha repulsión electrostática (ecuación [9]):
For $N F, V$ and $M$ admixtures, the total interaction potential energy has been calculated using two models: (a) considering the electrostatic repulsion negligible (equation [8]) and (b) taking it into account (equation [9]) (9):

$$
\mathrm{V}_{\mathrm{T}}=\mathrm{V}_{\mathrm{vdw}}+\mathrm{V}_{\text {elect }}+\mathrm{V}_{\text {steric }}
$$

Los parámetros utilizados y los resultados obtenidos se muestran en la Tabla 6 y Figura 12, respectivamente. En estos cálculos se consideraron las concentraciones de aditivo que conducían a la máxima disminución del esfuerzo de cizalla umbral en los ensayos reológicos, sin inducir segregación o sedimentación (ver Tabla 6 y (12)). En ausencia de aditivo, las partículas de escoria solo muestran potenciales atractivos lo que conduce a elevados esfuerzos de cizalla umbral en el rango entre 40 y 60 Pa (Tabla 6 (12)), lo que no es esperable en sistemas con bajos potenciales zeta (<-7 $\mathrm{mV}$ ) y una fuerza iónica de $0,025 \mathrm{M}$. La profundidad del pozo de potencial ha sido estimada para una máxima aproximación de partículas de $2 \mathrm{~nm}$. Este valor fue estimado considerando la existencia de la densa doble capa iónica así como de moléculas de agua fuertemente unidas a la superficie de la partícula como se ha visto previamente demostrado mediante simulaciones moleculares de fases minerales en elevadas concentraciones de sales (39) así como en previas modelizaciones del esfuerzo de cizalla umbral $(35,40)$.

Para los cuatro aditivos, a distancias cortas se observa una pronunciada barrera dispersiva a una distancia aproximada de $2 L_{\text {ads }}$ de cada aditivo. El valor de $L_{\text {ads }}$ utilizado en estos cálculos no es la media de los valores de $L_{\text {ads }}$ mostrados en la Tabla 4, sino dicha media más la desviación estándar.
The parameters used for the calculations are given in Table 6 and results shown graphically in Figure 12. The calculations were made at admixture concentrations that gave the minimum yield stress in rheology tests without inducing segregation and sedimentation (see Table 6 and (12)). Without superplasticizer the slag particles show only attractive potentials which leads to relatively high yield stresses between 40 and $60 \mathrm{~Pa}$ (Table 6 (12)), not unexpected for systems with low zeta potentials (<$7 \mathrm{mV}$ ) and an ionic strength of $0.025 \mathrm{M}$. The depth of the potential well was estimated for a closest approach of around $2 \mathrm{~nm}$. This was estimated from the dense ionic double layer and strongly bound water structure seen for mineral phases in high salt concentrations in molecular dynamic simulations (39) and previous yield stress modelling $(35,40)$.

For the four superplasticizers, at short distances a steep repulsive barrier is seen at distance close to the $2 L_{\text {ads }}$ for each superplasticizer. The $L_{\text {ads }}$ used for the calculations were not the average $L_{\text {ads }}$ from Table 4 but the average plus the standard deviation. This takes into account the 
De esta forma se tiene en cuenta la distribución de tamaño de los polímeros, de forma que, como se ha visto en trabajos anteriores, las moléculas más grandes tienden a dominar la repulsión estérica (28). A grandes distancias todos los aditivos muestran un mínimo de atracción, pero el valor de dicho mínimo así como la distancia de separación a la que se observan dependen del tipo de aditivo superplastificante. Estos valores de atracción mínimos son menores size distribution of the polymers as it has been previously shown that the longer molecules tend to dominate the steric repulsion (28). At larger distances all show shallow attractive minima of different depths and interparticle distances depending on the type of superplasticizer. These attractive minima are much shallower than the slag alone, and are in agreement with the significantly lower measured yield stresses, which were between 15

Tabla 6 / Table 6

Parámetros utilizados en los cálculos de las fuerzas entre partículas y esfuerzo de cizalla umbral. También se muestran la profundidad de los pozos de potencial y valores de esfuerzo de cizalla umbral predichos en pastas de escoria activada con $\mathrm{NaOH}(\mathrm{pH}=11,7)\left(\mathrm{D}_{\mathrm{v} 50}=16,4 \mu \mathrm{m}\right.$, concentración iónica $0,025 \mathrm{M}$, Valencia equivalente 1,16 (41) (* potencial zeta a la dosificación de aditivo que induce el mínimo esfuerzo de cizalla sin segregación). Parameters used for interparticle force and yield stress calculations, resulting potential well depths and measured and predicted yield stress values for slag pastes $\mathrm{pH} 11.7\left(D_{v 50}=16.4 \mu \mathrm{m}\right.$, ionic concentration $0.025 \mathrm{M}$, equivalent valence 1.16 (41) (* zeta potential at superplasticizer dose for minimum yield without segregation).

\begin{tabular}{|c|c|c|c|c|c|}
\hline Aditivo / Admixture & $\begin{array}{l}\text { Escoria sin aditivo / } \\
\text { slag without } \\
\text { admixture }\end{array}$ & $\begin{array}{c}\text { Escoria + NF / } \\
\text { Slag + NF }\end{array}$ & $\begin{array}{c}\text { Escoria }+M / \\
\text { Slag }+M\end{array}$ & $\begin{array}{c}\text { Escoria }+V / \\
\text { Slag }+V\end{array}$ & $\begin{array}{c}\text { Escoria + PC / } \\
\text { Slag + PC }\end{array}$ \\
\hline $\begin{array}{c}\text { Potencial zeta* / Zeta potential* } \\
\text { mV }\end{array}$ & -2.7 & -3.4 & -7.0 & -5.7 & -2.6 \\
\hline $\begin{array}{l}\text { Plano de potencial zeta / Zeta } \\
\text { potential plane } 0.5 \times \text { Lads (nm) }\end{array}$ & 0.5 & 0.8 & 1.1 & 1.3 & 1.0 \\
\hline $\begin{array}{l}\text { Máximo grosor de la capa de } \\
\text { aditivo adsorbido / Maximum } \\
\text { adsorbed layer thickness }(\mathrm{nm}) \$\end{array}$ & 0.0 & 1.76 & 2.16 & 2.28 & 3.36 \\
\hline $\begin{array}{c}\text { Profundidad del pozo de potencial } \\
\text { atractivo / Attractive well depth } \\
\text { (kT) } \\
\text { (Curva de potencial entre } \\
\text { partículas calculado de acuerdo a } \\
\text { la ec. [9] / interparticle potential } \\
\text { curve calculated according to } \\
\text { eq. [9]) }\end{array}$ & -3905 & -1864 & -1302 & -1234 & -819 \\
\hline $\begin{array}{c}\text { Profundidad del pozo de potencial } \\
\text { atractivo para un potencial } \\
\text { zeta }=0 \text { / Attractive well depth } \\
\text { zeta potential = } 0(k T) \\
\text { (curva de potencial entre partículas } \\
\text { calculado de acuerdo a ec. [8] / } \\
\text { interparticle potential curve } \\
\text { calculated according to eq. }[8])\end{array}$ & - & -1906 & -1450 & -1337 & -826 \\
\hline $\begin{array}{l}\text { Contribución electrostática a la } \\
\text { repulsión / Electrostatic } \\
\text { contribution to repulsion } \$(\%)\end{array}$ & & $2.2(5.1)$ & $10.2(26.2)$ & $7.7(11.0)$ & 0.8 \\
\hline $\begin{array}{c}\text { Posición del pozo atractivo = } \\
\text { distancia mínima de separación - } \\
\mathrm{H}-(\mathrm{nm})^{*} \text { / Attractive well position } \\
=\text { Minimum separation } \\
\text { distance- } H-(\mathrm{nm})\end{array}$ & 2.4 & $\begin{array}{c}3.6 \\
3.6^{*}\end{array}$ & $\begin{array}{l}4.5 \\
4.4^{*}\end{array}$ & $\begin{array}{l}4.8 \\
4.6^{*}\end{array}$ & $\begin{array}{c}6.9 \\
6.8^{*}\end{array}$ \\
\hline $\begin{array}{c}\text { Constante de Hamaker / Hamaker } \\
\text { constant } 10^{-20} \mathrm{~J}\end{array}$ & 2.2 & 2.1 & 2.0 & 2.0 & 1.8 \\
\hline $\begin{array}{c}\text { Esfuerzo de cizalla umbral medido } \\
\text { / Measured Yield stress } \mathrm{Pa}\end{array}$ & 56.2 & 16.6 & 15.7 & 19.3 & 4.9 \\
\hline $\begin{array}{l}\text { Esfuerzo de cizalla umbral predicho } \\
\text { / Predicted Yield stress Pa } \\
( \pm 15 \%)\end{array}$ & 65.3 & 30.0 & 18.3 & 16.1 & 7.0 \\
\hline
\end{tabular}

* Cambio en la profundidad y posición del pozo de potencial atractivo con la repulsión electrostática / * Change in attractive well depth and position with electrostatic repulsion.

\$Figuras en paréntesis han sido calculadas colocando el plano zeta al exterior del grosor de la capa de aditivo adsorbido $\mathrm{L}_{\text {ads. }} /$ \$ Figures in parenthesis are with the zeta plane at the full adsorbed layer thickness, $L_{a d s}$. 


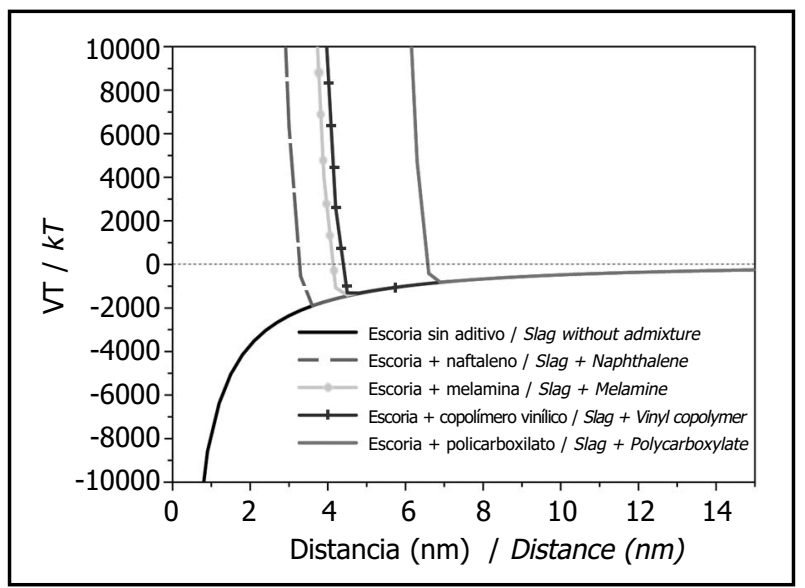

Figura 12. Curvas de potencial entre partículas en función de la separación entre la superficie de las partículas calculadas mediante el software Hamaker (18). Figure 12. Interparticle potential curves as a function of slag particles surface separation using the Hamaker software (18).

en los sistemas de escoria sin aditivos que con aditivos, lo que está de acuerdo con los valores de esfuerzo de cizalla umbral obtenidos, que son significativamente menores (con valores entre 15 y $20 \mathrm{~Pa}$ ) en los sistemas de escoria sin aditivo que con aditivo. La tendencia de los valores de esfuerzo de cizalla umbral están de acuerdo con los valores de la profundidad de pozo de potencial, de forma que el esfuerzo de cizalla umbral disminuye con la profundidad de dicho pozo. La única excepción la presenta el aditivo derivado de naftaleno, el cual tiene el menor peso molecular y el grosor de la capa de aditivo adsorbido determinado tiene una elevada desviación estándar, lo que hace muy difícil determinar $\mathrm{L}_{\text {ads }}$ de forma precisa.

Cuando la repulsión electroestática es despreciable (potencial zeta $=0$, ecuación [8]), se observa un cambio muy pequeño en el valor en la profundidad del pozo de atracción, por ejemplo, en el caso del aditivo copolímero vinílico, disminuye desde -1.337 a -1.234 kT, representando la repulsión electrostática menos del $8 \%$. Resultados similares se han obtenido para el resto de los aditivos superplastificantes como se muestra en la Tabla 6. El aditivo PC genera la máxima repulsión a pesar de tener un menor peso molecular que el aditivo copolímero vinílico. Esto ilustra la importancia de la estructura del polímero y de su conformación al adsorberse. La mayor repulsión estérica del aditivo $\mathrm{PC}$, de acuerdo con la bibliografía $(3,7)$, puede atribuirse a las cadenas laterales de grupos éteres que presentan estos aditivos, que induce una mayor fluidez. Los resultados obtenidos indican que el mecanismo de dispersión de los aditivos basados en sulfonatos y del aditivo basado en policarboxilato utilizados en el presente trabajo sobre pastas de AAS está dominado por fuerzas de repulsión de tipo estérico. La posibilidad de una infravaloración de la contribución estérica en aditivos no-PC fue indicada hace ya and $20 \mathrm{~Pa}$ in the presence of the superplasticizers. The trends in the yield stress correlate well with the calculated well depth, decreasing yield with decreasing well depth, which in turn correlates with the adsorbed layer thickness. The exception is the NF based superplasticizer where the very small molecular weight and hence adsorbed layer thickness shows the largest standard deviation make it difficult to assess the $L_{a d s}$ accurately.

When the electrostatic contribution is neglected (zeta = 0 , equation [8]) there is a small change in the attractive well depth e.g. for the vinyl copolymer superplasticizer it decreases to -1337 from $-1234 k T$ i.e the electrostatic contribution to the repulsion is less than $8 \%$ - similar results were found for the other superplasticizers as shown in Table 6. The PC admixture generated highest repulsion despite having a lower molecular weight than the vinyl copolymer based admixture. This illustrates the importance of the polymer structure and its adsorption conformation. The stronger steric repulsion, according to the literature $(3,7)$, can be attributed to the lateral ether group chains, which afforded it greater flowability. The results obtained indicate that the dispersion mechanism of both the sulphonate and polycarboxylates superplasticizers in the present study on AAS pastes are dominated by steric repulsion. The possibility of an underestimated steric contribution for non-PC type superplasticizers was in fact suggested by Banfill quite some time ago (42). The choice of the zeta potential plane may influence the electrostatic contribution but even if the zeta potential plane was placed at the 
varios años por Banfill (42). La elección del plano de potencial zeta puede influir en la contribución electrostática, sin embargo, incluso si el plano del potencial zeta se coloca a la distancia del grosor de la capa de aditivo adsorbido, la contribución electrostática a las fuerzas de dispersión supone todavía menos del 26\% (ver Tabla 6).

Utilizando los resultados de la evaluación de las fuerzas entre partículas mediante el programa Hamaker, fue posible utilizar el modelo YODEL para predecir el esfuerzo de cizalla umbral de pastas de escoria activada con $\mathrm{NaOH}$ a $\mathrm{pH}=11,7$. Los datos que se tienen que introducir en este modelo y los valores de esfuerzo de cizalla obtenidos se muestran en la Tabla 6, junto con los valores de esfuerzo de cizalla umbral determinados experimentalmente (12). El máximo empaquetamiento, $\phi_{\max }$, en pastas de escoria totalmente dispersas se determinó mediante filtrado a presión, obteniéndose un valor de 0,57 y el radio de curvatura de contacto considerado a* fue de $125 \mathrm{~nm}$. El valor de la constante de Hamaker utilizada estaba en el rango entre 2,2 y $1,810^{-20} \mathrm{~J}$, dependiendo de la mínima distancia de separación entre partículas, como se indica en la Tabla 6. Los valores del esfuerzo de cizalla umbral calculados son comparables a los experimentales. Como el modelo YODEL considera la distribución de tamaño de partículas, los cálculos de los valores de esfuerzo de cizalla umbral calculados entre diferentes pares de partículas han sido considerados $\left(D_{v 10}-D_{v 10}, D_{v 90}-D_{v 90}, D_{v 10}-D_{v 90}, D v_{50}-D_{v 90}, D_{v 10}-D_{v 50}\right)$. Esto influenciaba la mínima separación entre partículas y también los valores de constante de Hamaker considerados en el cálculo de las fuerzas. En general, los valores de esfuerzo de cizalla calculados se ajustan en un $\pm 15 \%$ a los valores experimentales. El valor que menos se ajusta al experimental es el esfuerzo de cizalla umbral calculado para el aditivo superplastificante derivado de naftaleno. Nuevamente creemos que la discrepancia se debe a la dificultad de determinar $\mathrm{L}_{\text {ads }}$ de forma precisa debido a su pequeño tamaño molecular. El hecho de que seamos capaces de captar el comportamiento reológico de estas pastas de escoria en medios alcalinos y en presencia de los aditivos superplastificantes es un resultado excelente y totalmente novedoso. El conocimiento del mecanismo de dispersión ayudará a diseñar nuevos superplastificantes que permitirá mejorar la eficacia, reducir la demanda de agua así como mejorar la microestructura, las propiedades y la durabilidad de estructuras de hormigón y contribuir así al desarrollo sostenible de este específico material de construcción.

\section{CONCLUSIONES}

Se han estudiado los mecanismos de dispersión de cuatro aditivos superplastificantes ( 3 basados en sulfonatos y uno en carboxilatos) en suspensiones de escorias maximum adsorbed layer thickness the electrostatic contribution to the dispersion force was still less than 26\% (Table 6).

Using the results from the Hamaker interparticle force evaluation it was possible to use the YODEL model to predict the expected yield stress for the slag pastes at $\mathrm{pH}$ 11.7. The input data for the YODEL model and the resulting yield stresses are presented in Table 6, along with the yield stress measured experimentally (12). The maximum packing fraction, $\phi_{\text {max }}$ for well dispersed slag pastes was measured to be 0.57 using filter pressing and the radius of curvature of contact a* was $125 \mathrm{~nm}$. The Hamaker constants used were between 2.2 and 1.8 10-20 J depending on the minimum separation distance as indicated in Table 6. The predicted values compare very well with the experimental yield stresses. Since the Yodel model is sensitive to the particle size distribution, calculations of predicted yield stress for different pairs of particles were made $\left(D_{v 10}-D_{v 10}, D_{v 90}-D_{v 90}, D_{v 10}-D_{v 90}\right.$, $\left.\left.D v_{50}-D_{v 90}, D_{v 10}-D_{v 50}\right)\right)$. This influenced the minimum separation of the particles and also the Hamaker constant used to calculate the interparticle force. The overall range of the calculated yield stresses were $\pm 15 \%$. The least satisfactory result is found with the NF based superplasticizer. Again we believe this discrepancy is due to the difficultly in assessing the $L_{a d s}$ accurately because of the small molecular size. That we capture the overall rheological behaviour of these slag pastes in alkaline media with superplasticizers is an excellent result. This profound understanding of the dispersion mechanism will help in the design of new superplasticizers that can improve efficiency, reduce water consumption and by improving microstructures improve properties and durability of concrete structures and contribute towards a sustainable development of this key construction material.

\section{CONCLUSIONS}

The dispersion mechanism of four superplasticizers, 3 sulphonate based and one carboxylate based, for ground granulated blast furnace slag suspensions in alkaline 
granuladas de horno alto en medios alcalinos. Los parámetros clave necesarios para modelizar las fuerzas entre partículas, utilizando el programa de Hamaker, son: el potencial zeta, el grosor de la capa adsorbida y una estimación de la constante de Hamaker de la propia escoria. Se determinó la constante efectiva de Hamaker a partir de medidas de propiedades dieléctricas en muestras de escoria previamente sinterizada. Valores de $2.2 \cdot 10^{-20} \mathrm{~J}$ a una distancia de separación entre partículas de alrededor de $2 \mathrm{~nm}$ son coherentes con los valores previamente estimados en sistemas cementantes y permiten validar aproximaciones previas recogidas en la literatura.

Las medidas de potencial zeta se realizaron utilizando métodos electroacústicos, y los resultados obtenidos muestran valores de potencial zeta negativos entre -3 and $-10 \mathrm{mV}$, dependiendo de la dosis y del tipo de aditivo. De acuerdo a los cálculos de potenciales entre partículas, en los sistemas de escoria activada con $\mathrm{NaOH}$ $(\mathrm{pH}=11,7)(0,025 \mathrm{M})$ la contribución electrostática de los aditivos estudiada es pequeña (menos del 10\%) en comparación con la contribución estérica.

Por primera vez se ha determinado el grosor de la capa de aditivo adsorbido en sistemas de escoria para evaluar la repulsión estérica. Las medidas realizadas mediante AFM en sistemas de escoria a $\mathrm{pH}=11,7$ han sido validadas utilizando un modelo no reactivo de $\alpha-\mathrm{Al}_{2} \mathrm{O}_{3}$. En ambos sistemas, $\alpha-\mathrm{Al}_{2} \mathrm{O}_{3}$ y escoria, se han determinado similares grosores de capa de aditivo adsorbido lo que indica que $\alpha-\mathrm{Al}_{2} \mathrm{O}_{3}$ es un buen modelo para sistemas de escoria. El aditivo derivado de naftaleno usado en el presente trabajo induce el menor grosor de capa de aditivo adsorbido $(\approx 1,3 \mathrm{~nm}$ ). El aditivo basado en policarboxilato, a pesar de presentar un menor peso molecular que los aditivos derivados de melamina y copolímero vinílico produce la mayor capa de aditivo adsorbido $(\approx 2,5 \mathrm{~nm})$. Esto puede atribuirse a su diferente estructura molecular y diferente conformación que adopta al adsorberse. No fue posible determinar la capa de aditivo adsorbido en sistemas de escoria a $\mathrm{pH}=13,6$ debido a la elevada reactividad de la escoria a este $\mathrm{pH}$. Sin embargo, los resultados obtenidos a partir de ensayos reológicos de pastas de escoria a los diferentes $\mathrm{pH}$ sugieren que el mecanismo de dispersión estérica es nuevamente el mecanismo dominante en el caso del aditivo derivado de naftaleno utilizado. Los valores de esfuerzo de cizalla umbral predichos por el método YODEL están de acuerdo con los datos experimentales. Esto nos proporciona una valoración semi-cuantitativa de este parámetro reológico en sistemas de escoria activada alcalinamente y nos ayudará a explotar en mayor medida este material en el futuro.

Las diferencias encontradas entre las diferentes moléculas y su diferente grosor de la capa de aditivo adsorbido indican que una modificación de las estructuras de las media has been investigated. The key parameters needed for the interparticle force modelling, using the Hamaker software, were the zeta potential, adsorbed layer thickness and an estimation of the Hamaker constant for blast furnace slag. An effective Hamaker constant was calculated using dielectric properties measured on sintered slag samples. The value of $2.2 x$ $10^{-20} \mathrm{~J}$ at particle separation distance of around $2 \mathrm{~nm}$ were coherent with values previously estimated for cementitious materials, and thus help validate the previous approaches.

Zeta potential measurements were made using the electroacoustic method and showed low negative zeta potentials between -3 and $-10 \mathrm{mV}$ depending the dosage and type of admixture. The electrostatic contribution was found from interparticle potential calculations to be low (less than $10 \%$ ) compared to steric contribution at the ionic strengths found in slag pore solutions at $\mathrm{pH}=11.7$ $(0.025 \mathrm{M})$ for the superplasticizers studied.

To evaluate the steric repulsion, for first time, adsorbed polymer layer thickness has been determined in slag systems. The AFM measurements carried out in slag systems at $\mathrm{pH}=11.7$ were validated using a non-reactive model of $\alpha-\mathrm{Al}_{2} \mathrm{O}_{3}$. The similarity in the adsorbed layer thicknesses measured for $\alpha-\mathrm{Al}_{2} \mathrm{O}_{3}$ and the slag systems indicate that $\alpha-\mathrm{Al}_{2} \mathrm{O}_{3}$, is a very good model for slag systems. The naphthalene-based admixture used in the present work had the lowest average adsorbed layer thickness $(\approx 1.3 \mathrm{~nm})$. Polycarboxylate-based admixture produces the highest layer thickness $(\approx 2.5 \mathrm{~nm})$ despite having a lower molecular weight than the melamine and vinyl copolymer admixtures. This can be attributed to its different molecular structure and adsorbed conformation. It was not possible to determine the adsorbed polymer layer thickness in slag systems at $\mathrm{pH}=13.6$ due to the high reactivity of the slag at this $\mathrm{pH}$ but similarity between the rheological behaviour for the naphthalene admixture at different $\mathrm{pHs}$ suggest that the dominant dispersion mechanism is again the steric contribution for this particular admixture. The predicted yield stresses using all these data in the YODEL yield stress model showed in general good agreement with experimental data. This now gives us at least a semiquantitative assessment of this rheological parameter for alkali-activated slag systems and will help us further exploit them in the future.

The differences between the different molecules and their different adsorbed layer thickness indicate that modification of polymer structures, which can be verified 
moléculas, que podría ser verificado mediante AFM, podría permitir mejoras en la dispersión de pastas de escoria activada alcalinamente y contribuir a la mejora de las propiedades de estos ecoeficientes cementos y hormigones y contribuir de esta forma al desarrollo sostenible.

\section{AGRADECIMIENTOS}

Los autores agradecen al Ministerio de Ciencia y Tecnología (MCyT) de España, la concesión del proyecto BIA 2010-15516. También agradecen a Carlos Morais y Uwe Rietzler su ayuda en las medidas del potencial zeta y AFM, respectivamente. Dan las gracias al Dr. Zhao Zhe por la preparación de los sustratos de escoria. M. Palacios trabajó con un contrato postdoctoral otorgado por CSIC y una ayuda de movilidad José Castillejo (MICINN). by AFM measurements, should allow further improvements in the dispersion of alkali-activated slag pastes and contribute to a lower carbon foot print and improved cement and concrete properties in our quest towards a sustainable development.

\section{ACKNOWLEDGEMENTS}

Funding for project BIA 2010-15516 was provided by the Spanish Ministry of Science and Technology (MCYT). The authors wish to thank Carlos Morais for help with the zeta potential measurements and to Uwe Rietzler for help the AFM measurements. Also, we thank Dr. Zhao Zhe for preparing the slag substrates. M. Palacios worked under postdoctoral contract awarded by the CSIC and "Jose Castillejo" grant (MICINN).

\section{BIBLIOGRAFÍA / BIBLIOGRAPHY}

(1) Mollah, M. Y. A.; Adams, W. J.; Schennach, R.; Cocke, D. L.: "A review of cement - superplasticizer interactions and their models", Adv. Cem. Res. (2000); 12, pp. 153-161. http://dx.doi.org/10.1680/adcr.2000.12.4.153

(2) Houst, Y.; Bowen, P.; Siebold, A.: Some basic aspects of the interaction between cement and superplasticizers. Innovations and developments in Concrete Materials and Construction. Ed. R. K. Dhir, P. C. Hewlett, L. J. Csetenvi; (2002), pp. 225-234.

(3) Alonso, M. M.; Palacios, M.; Puertas, F.; de la Torre, A. G.; Aranda, M. A. G.: "Effect of polycarboxylate admixture structure on cement paste rheology", Mater. Construcc. (2007); 57, n. 286, pp. 65-81.

(4) Flatt, R.; Houst, Y.: "A simplified view on chemical effects perturbing the action of superplasticizers", Cem. Concr. Res. (2001); 31, pp. 1169-1176. http://dx.doi.org/10.1016/S0008-8846(01)00534-8

(5) Zingg, A.; Winnefeld, F.; Holzer, L.; Pakusch, J.; Becker, S.; Gauckler, L.: "Adsorption of polyelectrolytes and its influence on the rheology, zeta potential, and microstructure of various cement and hydrate phases", J. Coll. Interface Sci. (2008); 323, pp. 301-312. http://dx.doi.org/10.1016/j.jcis.2008.04.052 PMid:18502439.

(6) Uchikawa, H.; Hanehara, S.; Sawaki, D.: "The role of steric repulsive force in the dispersion of cement particles in fresh paste prepared with organic admixture", Cem. Concr. Res. (1997); 27, pp. 37-50. http://dx.doi.org/10.1016/S0008-8846(96)00207-4

(7) Flatt, R.; Schober, I.; Raphael, E.; Plassard, C.; Lesniewska, E.: "Conformation of Adsorbed Comb Copolymer Dispersants", Langmuir (2009); 25, pp. 845-855. http://dx.doi.org/10.1021/la801410e,PMid:19086886.

(8) Houst, Y. F.; Bowen, P.; Perche, F.; Kauppi, A.; Borget, P.; Galmichei, L.; Le Meins, J.-F.; Lafuma, F.; Flatt, R. J.; Schober, I.; Banfill, P. F. G.; Swift, D. S.; Myrvold, B. O.; Petersen, B. G.; Reknes, K.: "Design and function of novel superplasticizers for more durable high performance concrete (superplast project)", Cem. Concr. Res. (2008); 38, pp. 1197-1209. http://dx.doi.org/10.1016/j.cemconres.2008.04.007 (9) Ran, Q.; Somasundaran, P.; Miao, C.; Liu, J.; Wu, S.; Shen, J.: "Effect of the length of the side chains of comb-like copolymer dispersants on dispersion and rheological properties of concentrated cement suspensions", J. Coll. Interface Sci. (2009); 336, pp. 624633. http://dx.doi.org/10.1016/j.jcis.2009.04.057 PMid:19500795.

(10) Sánchez, R.; Palacios, M.; Puertas, F.: "Characteristics and propierties of oil-well cements additioned with blast furnace slag", Mater. Construcc. vol. 61, n. 302, (2011), pp. doi: 10.3989/mc.2010.54110

(11) Puertas, F.: "Cementos de Escoria Activados Alcalinamente: Situación Actual y Perspectivas de Futuro", Mater. Construc. (1995); 45, n. 239, pp. 53-64. http://dx.doi.org/10.3989/mc.1995.v45.i239.553

(12) Palacios, M.; Houst, Y. F.; Bowen, P.; Puertas, F.: "Adsorption of superplasticizer admixtures on alkali-activated slag pastes", Cem. Concr. Res. (2009); 39, pp. 670-677. http://dx.doi.org/10.1016/j.cemconres.2009.05.005

(13) Palacios, M.; Banfill, P. F. G.; Puertas, F.: "Rheology and Setting of Alkali-Activated Slag Pastes and Mortars: Effect of Organic Admixture", ACI Materials Journal (2008); 105, pp. 140-148.

(14) Bakharev, T.; Sanjayan, J. G.; Cheng, Y.-B.: "Effect of admixtures on properties of alkali-activated slag concrete", Cem. Concr. Res. (2000); 30, pp. 1367-1374. http://dx.doi.org/10.1016/S0008-8846(00)00349-5

(15) Palacios, M.; Puertas F.: "Effect of superplasticizer and shrinkage-reducing admixtures on alkali-activated slag pastes and mortars", Cem. Concr. Res. (2005; 35, pp. 1358-1367. http://dx.doi.org/10.1016/j.cemconres.2004.10.014 
Fuerzas de repulsión de aditivos superplastificantes en sistemas de escoria granulada de horno alto en medios alcalinos, desde medidas de AFM a propiedades reológicas Repulsion forces of superplasticizers on ground granulated blast furnace slag in alkaline media, from AFM measurements to rheological properties

(16) Palacios, M.; Puertas, F.: "Stability of superplasticizer and Shrinkage-reducing admixtures in high basic media", Mater. Construcc. (2004); 54, n. 276, pp. 65-86. http://dx.doi.org/10.3989/mc.2004.v54.i276.256.

(17) Flatt, R. J.; Bowen, P.: "Yodel: A Yield Stress Model for Suspensions", J. Am. Ceram. Soc. (2006); 89 [4], pp. $1244-1256$. http://dx.doi.org/10.1111/j.1551-2916.2005.00888.x

(18) Hamaker software download; http://ltp.epfl.ch/page65254.html - see also reference 28

(19) Flatt, R. J.: "Dispersion forces in cement suspensions", Cem. Concr. Res. (2004); 34, pp. 399-408. http://dx.doi.org/10.1016/j.cemconres.2003.08.019.

(20) Palacios, M.; Sierra, C.; Puertas, F.: "Techniques and methods of characterization of admixtures for concrete", Mater Construc. (2003): vol. 53, n. 269, pp. 89-105. http://dx.doi.org/10.3989/mc.2003.v53.i269.262

(21) Stark, R.: Surface layer formation in polymer melts and in solutions, PhD thesis, University of Mainz, (2007).

(22) Stark, R.; Nicoleau, L.; Hübsch, C.; Kappl, M.; Butt, H. J.: 3rd Meeting of the German Colloid Society, Mainz, Germany, (2007).

(23) Ferrari, L.; Kaufmann, J.; Winnefeld, F.; Plank, J.: "Interaction of cement model systems with superplasticizers investigated by atomic force microscopy, zeta potential, and adsorption measurements", J. Coll. Interface Sci. (2010); 347, pp. 15-24. http://dx.doi.org/10.1016/j.jcis.2010.03.005 PMid:20356605.

(24) Kauppi, A.; Andersson, K. M.; Bergström, L.: "Probing the effect of superplasticizer adsorption on the surface forces using the colloidal probe AFM technique", Cem. Concr. Res. (2005); 35, pp. 133-140. http://dx.doi.org/10.1016/j.cemconres.2004.07.008

(25) Díaz-Benito, B.; Velasco, F.; Guzmán, S.; Calabrés, R.: "AFM study of steel corrosion in aqueous solutions in concrete", Mater. Construcc., vol 61, no 301, (2011), pp. 27-37. doi: 10.3989/mc.2010.59410.

(26) Bowen, P.; Carry, C.; Luxembourg, D.; Hofmann, H.: "Colloidal processing and sintering of nanosized transition aluminas" Powder Technology, (2005); 157, pp. 100-107. http://dx.doi.org/10.1016/j.powtec.2005.05.015

(27) Stuer, M.; Zhao, Z.; Aschauer, U.; Bowen, P.: "Transparent polycrystalline alumina using spark plasma sintering: Effect of Mg, Y and La doping", J. Eur Ceram Soc. (2010); 30, pp. 1335-1343. http://dx.doi.org/10.1016/j.jeurceramsoc.2009.12.001

(28) Pederson, H. G.; Bergström, L.: "Forces Measured between Zirconia Surfaces in Poly(acrylic acid) Solutions", J. Am. Ceram. Soc. (1999); 82 (5), pp. 1137-1145. http://dx.doi.org/10.1111/j.1151-2916.1999.tb01887.x

(29) Butt, H.-J.; Cappella, B.; Kappl, M.: "Force measurements with the atomic force microscope: Technique, interpretation and applications", Surface Science Reports (2005); 59, pp. 1-152. http://dx.doi.org/10.1016/j.surfrep.2005.08.003

(30) Pecharromán, C.; Iglesias, J. E.: "A method for the determination of infrared optical constants from reflectance measurements on powdered samples", J. Phys. Condens Matter. (1994); 6, pp. 7125-7141. http://dx.doi.org/10.1088/0953-8984/6/35/021

(31) Russel, W. B.; Saville, D. A.; Schowalter, W. R.: Colloidal Dispersions. Cambridge Press, Cambridge, U.K., (1985).

(32) Aschauer, U.; Burgos-Montes, O.; Moreno, R.; Bowen, P.: "Hamaker 2: A toolkit for the calculation of particle interactions and suspension stability and its application to mullite synthesis by colloidal methods", J. Dispersion Science Technology, (2011); 32(4), pp. 470-479 http://dx.doi.org/10.1080/01932691003756738

(33) Song, S.; Sohn, D.; Jennings, H. M.; Mason, T. O.: "Hydration of alkali-activated ground granulated blast furnace slag", J. Mat. Scien. (2000); 35, pp. 249-257. http://dx.doi.org/10.1023/A:1004742027117

(34) Lewis, J. A.; Matsuyama, H.; Kirby, G.; Morissette, S.; Young, J. F.: "Polyelectrolyte Effects on the Rheological Properties of Concentrated Cement Suspensions", J. Am. Ceram. Soc. (2000); 83 (8), pp. 1905-1913. http://dx.doi.org/10.1111/j.11512916.2000.tb01489.x

(35) Flatt, R. J.; Bowen, P.: "Yield Stress of Multimodal Powder Suspensions: An Extension of the YODEL (Yield Stress mODEL)", J. Am Ceram Soc. (2007); 90 (4), pp. 1038-1044. http://dx.doi.org/10.1111/j.1551-2916.2007.01595.x

(36) Nägele, E.; Schneider U.: "The zeta-potential of blast furnace slag and fly ash", Cem. Concr. Res. (1989); 19, pp. 811-820. http://dx.doi.org/10.1016/0008-8846(89)90052-5

(37) Palacios, M.; Puertas, F.; Bowen, P.; Houst, Y. F.: "Effect of PCs on the rheological properties and hydration process of slag portland cement pastes", J. Mat. Scien. (2009); 44, pp. 2714-2723. http://dx.doi.org/10.1007/s10853-009-3356-4

(38) Yilmaz, H.; Sato, K.; Watari, K.: "AFM interaction study of --alumina particle and c-sapphire surfaces at high-ionic-strength electrolyte solutions", J. Coll. Interface Sci. (2007); pp. 307: 116-123. http://dx.doi.org/10.1016/j.jcis.2006.11.010 PMid:17161413.

(39) Kerisit, S.; Cooke, D. J.; Marmier, A.; Parker, S. C.: "Atomistic simulation of charged iron oxyhydroxide surfaces in contact with aqueous solution", Chemical Communications (2005); 24, pp. 3027-3029. http://dx.doi.org/10.1039/b503899e PMid:15959573.

(40) Roussel, N.; Lemaître, A; Flatt, R. J.; Coussot, P.: "Steady state flow of cement suspensions: A micromechanical state of the art", Cem. Concr. Res. (2010); 40, pp. 77-84. http://dx.doi.org/10.1016/j.cemconres.2009.08.026

(41) Flatt, R. J.; Bowen, P.: "Electrostatic repulsion between particles in cement suspensions: Domain of validity of linearized PoissonBoltzmann equation for nonideal electrolytes", Cem. Concr. Res. (2003); 33, pp. 781-791. http://dx.doi.org/10.1016/S00088846(02)01059-1

(42) Banfill, P. F. G.: A discussion of the papers "Rheological properties of cement mixes by M. Daimon and D. M. Roy". Cem Concr Res (1979); 9, pp. 795-796. http://dx.doi.org/10.1016/0008-8846(79)90075-9 